\title{
Microbial dynamics in a High Arctic glacier forefield: a combined field, laboratory, and modelling approach
}

\author{
James A. Bradley ${ }^{1,2,6}$, Sandra Arndt ${ }^{2}$, Marie Šabacká ${ }^{1}$, Liane G. Benning ${ }^{3,4}$, Gary L. Barker ${ }^{5}$, Joshua J. Blacker ${ }^{3}$, \\ Marian L. Yallop ${ }^{5}$, Katherine E. Wright ${ }^{1}$, Christopher M. Bellas ${ }^{1}$, Jonathan Telling ${ }^{7}$, Martyn Tranter ${ }^{1}$, and \\ Alexandre M. Anesio ${ }^{1}$ \\ ${ }^{1}$ Bristol Glaciology Centre, School of Geographical Sciences, University of Bristol, BS8 1SS, UK \\ ${ }^{2}$ BRIDGE, School of Geographical Sciences, University of Bristol, BS8 1SS, UK \\ ${ }^{3}$ School of Earth and Environment, University of Leeds, LS2 9JT, UK \\ ${ }^{4}$ GFZ, German Research Centre for Geosciences, 14473 Potsdam, Germany \\ ${ }^{5}$ School of Biological Sciences, University of Bristol, BS8 1SS, UK \\ ${ }^{6}$ Department of Earth Sciences, University of Southern California, Los Angeles, CA, USA \\ ${ }^{7}$ School of Civil Engineering and Geosciences, Newcastle University, UK \\ Correspondence to: James A. Bradley (j.bradley@bristol.ac.uk)
}

Received: 14 February 2016 - Published in Biogeosciences Discuss.: 16 February 2016

Revised: 14 September 2016 - Accepted: 26 September 2016 - Published: 13 October 2016

\begin{abstract}
Modelling the development of soils in glacier forefields is necessary in order to assess how microbial and geochemical processes interact and shape soil development in response to glacier retreat. Furthermore, such models can help us predict microbial growth and the fate of Arctic soils in an increasingly ice-free future. Here, for the first time, we combined field sampling with laboratory analyses and numerical modelling to investigate microbial community dynamics in oligotrophic proglacial soils in Svalbard. We measured low bacterial growth rates and growth efficiencies (relative to estimates from Alpine glacier forefields) and high sensitivity of bacterial growth rates to soil temperature (relative to temperate soils). We used these laboratory measurements to inform parameter values in a new numerical model and significantly refined predictions of microbial and biogeochemical dynamics of soil development over a period of roughly 120 years. The model predicted the observed accumulation of autotrophic and heterotrophic biomass. Genomic data indicated that initial microbial communities were dominated by bacteria derived from the glacial environment, whereas older soils hosted a mixed community of autotrophic and heterotrophic bacteria. This finding was simulated by the numerical model, which showed that active microbial communities play key roles in fixing and recycling carbon and nutrients. We also demonstrated the role of allochthonous carbon and
\end{abstract}

microbial necromass in sustaining a pool of organic material, despite high heterotrophic activity in older soils. This combined field, laboratory, and modelling approach demonstrates the value of integrated model-data studies to understand and quantify the functioning of the microbial community in an emerging High Arctic soil ecosystem.

\section{Introduction}

Polar regions are particularly sensitive to anthropogenic climate change (Lee, 2014) and have experienced accelerated warming in recent decades (Johannessen et al., 2004; Serreze et al., 2000; Moritz et al., 2002). The response of terrestrial polar ecosystems to this warming is complex, and research to understand the response of terrestrial ecosystems in high latitudes to environmental change is of increasing importance. A visible consequence of Arctic warming is the large-scale retreat of glacier and ice cover (ACIA; 2005; Paul et al., 2011; Staines et al., 2014; Dyurgerov and Meier, 2000). From underneath the ice, a new terrestrial biosphere emerges, playing host to an ecosystem which may exert an important influence on biogeochemical cycles and more specifically atmospheric $\mathrm{CO}_{2}$ concentrations and associated climate feedbacks 
(Dessert et al., 2003; Anderson et al., 2000; Smittenberg et al., 2012; Berner et al., 1983).

Numerous studies have attempted to characterize the physical and biological development of recently exposed soils using a chronosequence approach, whereby a transect perpendicular to the retreating ice snout represents a time sequence with older soils at increasing distances from the ice snout (Schulz et al., 2013). We have recently shown that microbial biomass and macronutrients (such as carbon, phosphorus, and nitrogen) can accumulate in soils over timescales of decades to centuries (Bradley et al., 2014). In such pristine glacial forefield soils the activity of microbial communities is thought to be responsible for this initial accumulation of carbon and nutrients. Such an accumulation facilitates colonization by higher-order plants, leading to the accumulation of substantial amounts of organic carbon (Insam and Haselwandter, 1989). However, organic carbon may also be derived from allochthonous sources such as material deposited on the soil surface (from wind, hydrology, precipitation, and ornithogenic sources) and ancient organic pools derived from under the glacier (Schulz et al., 2013). Nevertheless, the relative significance of allochthonous and autochthonous sources of carbon to forefield soils, as well as their effect on ecosystem behaviour, is so far still poorly understood (Bradley et al., 2014). Moreover, cycling of bioavailable nitrogen (which is derived from active nitrogen-fixing organisms, allochthonous deposition, and degradation of organic substrates) and phosphorus (liberated from the weathering of minerals and degradation of organic substrates) is similarly poorly quantified.

Several studies have observed shifts in the microbial community inhabiting pro-glacial soils of various ages (Zumsteg et al., 2011, 2012). This was expressed in increasing rates of autotrophic and bacterial production with soil age (Schmidt et al., 2008; Zumsteg et al., 2013; Esperschutz et al., 2011; Frey et al., 2013) and the overall decline in quality of organic substrates in older soils (Goransson et al., 2011; Insam and Haselwandter, 1989). However, current evidence is limited to mostly descriptive approaches, which may be challenging to interpret due to inherent difficulties in disentangling interacting microbial and geochemical processes across various temporal and spatial scales. Furthermore, the inherent heterogeneity of glacial forefield soils makes the development of a single conceptual model that fits all challenging. Accordingly, pro-glacial biogeochemical processes that dominate such systems remain poorly quantified and highly under-explored. This current lack of understanding limits our ability to predict the future evolution of these emerging landscapes and the potential consequences on global climate. $\mathrm{Nu}-$ merical models present an opportunity to expand our knowledge of glacier forefield ecosystems by analytically testing the hypotheses that arise from observations as well as extrapolating, interpolating, and budgeting processes, rates, and other features to explore beyond the possibility of empirical observation (Bradley et al., 2016). With such a model we can then also explore the sensitivity and resilience of these ecosystems to environmental change.

Here, we have combined field observations with laboratory incubations and elemental measurements as well as genomic analyses and used these in a numerical model to investigate the development of soils in a glacial forefield. The present study forms an important part of the integrated and iterative model-data approach outlined in the model description and testing (Bradley et al., 2015) whereby initial model development was informed by decades of empirical research, new data and laboratory experiments (presented here) are used to refine and inform model simulations, and so forth. With these data we refined some model parameters in the recently developed Soil biogeocHemIcal Model for Microbial Ecosystem Response (SHIMMER 1.0; Bradley et al., 2015) model and applied this to the emerging forefield of Midtre Lovénbreen in Svalbard. Pioneer soils in the High Arctic and Antarctica, such as the Midtre Lovénbreen forefield, are ideal sites to test this field-laboratory-model approach due to the lack of vegetation during initial stages of soil development, as the presence of vegetation would obscure the microbial community dynamics and considerably alter the physical properties of the soil (Brown and Jumpponen, 2014; Ensign et al., 2006; King et al., 2008; Kastovska et al., 2005; Schutte et al., 2009; Duc et al., 2009). The model development was informed by decades of empirical research on glacier forefield soils, and has already been tested and validated using published datasets from the Damma Glacier in Switzerland and the Athabasca Glacier in Canada. A thorough sensitivity analysis highlighted the most important parameters to constrain in order to make further predictions more robust. All our model parameter values are specific to individual, local model conditions and inherently contain necessary model simplifications, abstractions, and assumptions. Nevertheless, our earlier sensitivity analyses revealed the following highly sensitive key parameters as the most important to constrain through measurements: the maximum heterotrophic growth rate $\left(I_{\operatorname{maxH}}\right)$, the bacterial growth efficiency (BGE, parameter $\left.Y_{\mathrm{H}}\right)$, and the temperature response $\left(Q_{10}\right)$.

Therefore, in this current study, we combined detailed field measurements with specifically designed laboratory experiments and quantified values for these three parameters with a specific set of soils from the Midtre Lovénbreen forefield. The laboratory experiments and measurements were conducted with the objective to better constrain these sensitive parameters. We then ran model simulations in order to explore the ranges of model output and refine model predictions compared to the previous range identified in Bradley et al. (2015). Next, we examined model output to explore the microbial and biogeochemical dynamics of recently exposed soils in the Midtre Lovénbreen catchment and evaluate two main hypotheses. First, we tested the hypothesis that microbial biomass in recently exposed soils accumulates due to in situ bacterial growth and activity. It is commonly observed in glacier forefields that microbial biomass accumulates with 


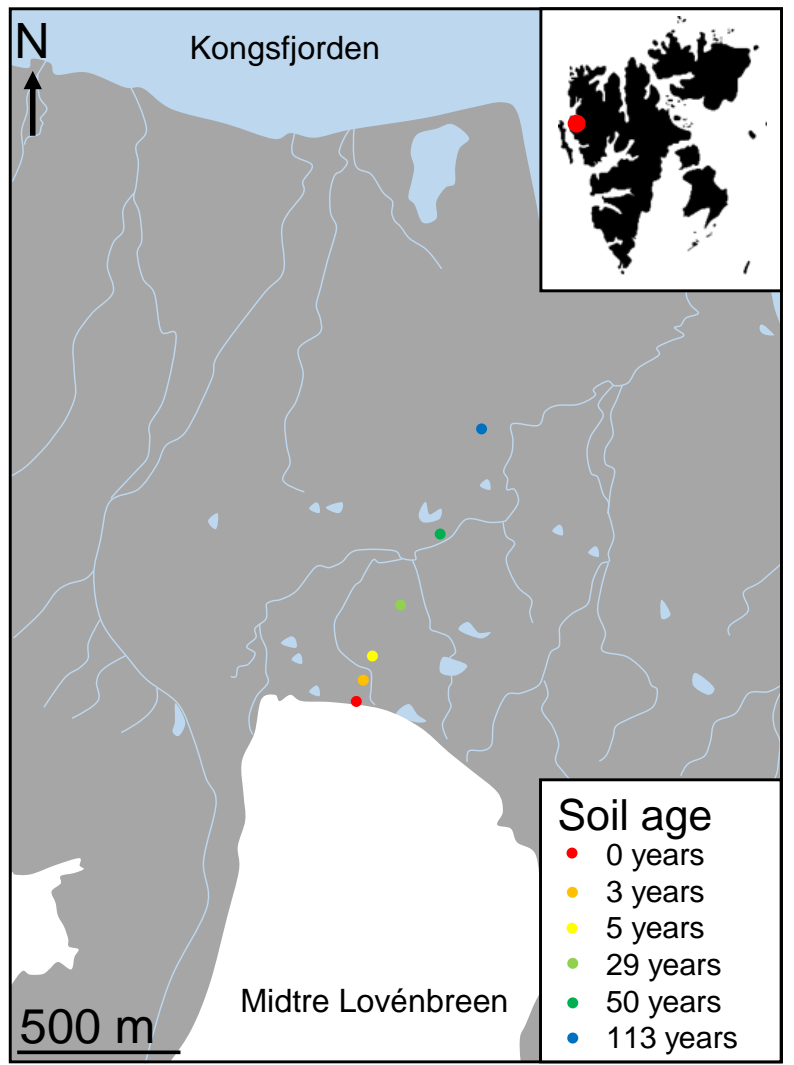

Figure 1. Midtre Lovénbreen glacier and forefield in Svalbard, the location of sampling sites, and approximate age of soil.

increasing soil age following exposure (Bernasconi et al., 2011; Schulz et al., 2013; Bradley et al., 2014). This study provides a new quantitative and process-focused approach to examine in situ growth in pioneer ecosystems and assess the role of different functional groups in biomass accumulation. Second, we tested the hypothesis that carbon fluxes in very recently exposed soils are low and are dominated by (abiotic) deposition of allochthonous substrate, whereas carbon fluxes are high in older soils due to increased microbial (biotic) activity (such as microbial growth, respiration, and cell death). Increased soil carbon fluxes with soil age have been linked to microbial activity from the forefield of the Damma Glacier, Switzerland (Smittenberg et al., 2012; Guelland et al., 2013b). With this combined model, field, and lab study, we were able to estimate carbon fluxes between ecosystem components with daily resolution and provide new insight into the interplay of processes that contribute to net ecosystem production and soil organic carbon stocks in a High Arctic system.

\section{Methods}

\subsection{Study site and sampling}

Midtre Lovénbreen is an Arctic polythermal valley glacier on the south side of Kongsfjorden, western Svalbard $\left(78^{\circ} 55^{\prime} \mathrm{N}\right.$, $12^{\circ} 10^{\prime} \mathrm{E}$; Fig. 1). The Midtre Lovénbreen catchment is roughly $5 \mathrm{~km}$ east of $\mathrm{Ny}$-Ålesund, where several long-term monitoring programmes have provided a wealth of contextual information. Midtre Lovénbreen has experienced negative mass balance throughout much of the 20th century. Since the end of the Little Ice Age (maximum in Svalbard in the 1900s) the de-glaciated surface area of the Midtre Lovénbreen catchment has increased considerably in response to warming mean annual temperatures. This expansion of deglaciated surface area continues to the present day. Between 1966 and 1990, $\sim 2.3 \mathrm{~km}^{2}$ of land was exposed (Fleming et al., 1997; Moreau et al., 2008). We used a chronosequence approach to determine ages for soils based on satellite imagery (Landsat TM 7) and previously determined soil ages by aerial photography and ${ }^{14} \mathrm{C}$ dating techniques in Hodkinson et al. (2003). Soil samples were collected along a transect perpendicular to the glacier snout, representing soil ages of $0,3,5,29,50$, and 113 years (Fig. 1) during the field season (18 July to 29 August 2013). At each of the six sites along the chronosequence, $10 \mathrm{~m}$ traverses roughly parallel to the glacier snout were established and at each site three soil plots were sampled (using ethanol-sterilized sampling equipment). After removing the $>2 \mathrm{~cm}$ rock pieces at each site, about $100 \mathrm{~g}$ of soil was collected from the top $15 \mathrm{~cm}$ and immediately placed into sterile, high-density polyethylene bags (Whirl-Pak; Lactun, Australia) and into a cool box partially filled with cool packs and dry ice. Samples were immediately frozen and stored at $-20^{\circ} \mathrm{C}$ on return to the UK Arctic Research station in Ny-Ålesund (no longer than $5 \mathrm{~h}$ after collection). Samples were transported frozen on dry ice to the laboratories in the universities of Bristol and Leeds (UK).

\subsection{Laboratory analyses}

For bacterial abundance, samples were thawed and aliquots $(100 \mathrm{mg})$ were immediately transferred into sterile $1.5 \mathrm{~mL}$ microcentrifuge (Eppendorf) tubes, where they were diluted with $900 \mu \mathrm{L}$ of Milli-Q water $(0.2 \mu \mathrm{m}$ filtered) and immediately fixed in $100 \mu \mathrm{L}$ glutaraldehyde $(0.2 \mu \mathrm{m}$ filtered, $2.5 \%$ final concentration). Samples were then vortexed for $10 \mathrm{~s}$ and sonicated for $1 \mathrm{~min}$ at $30^{\circ} \mathrm{C}$ to facilitate cell detachment from soil particles. Thereafter, $10 \mu \mathrm{L}$ of fluorochrome DAPI ( $4^{\prime}, 6$ diamidino-2 phenylindole) was added to half of the samples and then tubes were vortexed briefly ( $3 \mathrm{~s})$ and incubated in the dark for $10 \mathrm{~min}$ in order to be counted under UV light. The other half of each sample remained untreated, for counting under auto-fluorescent light for photosynthetic pigmentation. Samples were vortexed for $10 \mathrm{~s}$ and left to stand for a further $30 \mathrm{~s}$ to ensure a well-mixed solution, prior to filter- 
ing $100 \mu \mathrm{L}$ of the mixed liquid sample onto black Millipore Isopore membrane filters $(0.2 \mu \mathrm{m}$ pore size, $25 \mathrm{~mm}$ diameter), rinsed with a further $250 \mu \mathrm{L}$ of Milli-Q water $(0.2 \mu \mathrm{m}$ filtered). Bacterial cells were then counted using an Olympus BX41 microscope at $1000 \times$ magnification. The filtering apparatus was washed out with Milli-Q water between each filtration, and negative control samples, prepared using Milli-Q water, were included into each series. A negative control was a sample with no visible stained or auto-fluorescing cells. Thirty random grids (each $10^{4} \mu \mathrm{m}^{2}$ ) were counted per sample. Cell morphologies were measured and cell volume was estimated and converted to carbon content according to Bratbak and Dundas (1984; see Supplement). Separate aliquots of soil from each site were weighed after thawing and then dried at $105^{\circ} \mathrm{C}$ to obtain an estimate of soil moisture content.

Environmental DNA was isolated from at least three replicates for each soil age using a MoBio PowerMax ${ }^{\circledR}$ soil DNA isolation kit and by following the instruction manual. A total of 5 to $10 \mathrm{~g}$ of soil was used per sample to isolate DNA. Following extraction, DNA was diluted to equimolar concentrations, so that all samples contained $7.0 \mathrm{ng}$ of DNA, prior to amplification. The isolated genomic DNA was amplified with bacterial primers 515f (5'-GTGYCAGCMGCCGCGGTAA-3') and 926r (5'CCGYCAATTYMTTTRAGTTT-3'; Caporaso et al., 2012), creating a single amplicon of $\sim 400 \mathrm{bp}$. The reaction was carried out in $50 \mu \mathrm{L}$ volumes containing $0.3 \mathrm{mg} \mathrm{mL}^{-1}$ bovine serum albumin, $250 \mu \mathrm{M}$ dNTPs, $0.5 \mu \mathrm{M}$ of each primer, $0.02 \mathrm{U}$ Phusion high-fidelity DNA polymerase (Finnzymes OY, Espoo, Finland), and $5 \times$ Phusion HF buffer containing $1.5 \mathrm{mM} \mathrm{MgCl} 2$. The following PCR conditions were used: initial denaturation at $95^{\circ} \mathrm{C}$ for $5 \mathrm{~min}$, followed by $25 \mathrm{cy}$ cles consisting of denaturation $\left(95^{\circ} \mathrm{C}\right.$ for $\left.40 \mathrm{~s}\right)$, annealing $\left(55^{\circ} \mathrm{C}\right.$ for $\left.2 \mathrm{~min}\right)$, and extension $\left(72^{\circ} \mathrm{C}\right.$ for $\left.1 \mathrm{~min}\right)$ and a final extension step at $72^{\circ} \mathrm{C}$ for $7 \mathrm{~min}$. Following amplification, all amplicons were normalized to the same concentration $(9.0 \mathrm{ng})$ before sequencing. Samples were sequenced using the Ion Torrent platform (using an Ion 318v2 chip) at Bristol Genomics facility at the University of Bristol. Samples were barcoded in the PCR stage and demultiplexed in QIIME using split_libraries.py code (Caporaso et al., 2010). A non-barcoded library was prepared from the amplicon pool using a Life Technologies Short Amplicon Prep Ion Plus Fragment Library kit. The template and sequencing kits used were an Ion PGM Template OT2 400 kit and an Ion PGM Sequencing 400 kit. The sequencing yielded 4.38 million reads. The $16 \mathrm{~S}$ sequences were further processed using MOTHUR (v. 1.35) and QIIME pipelines (Schloss et al., 2009; Caporaso et al., 2010). Initially, sequences that were too short, too long, or low quality were removed in MOTHUR. Chimeric sequences were identified and removed using UCHIME (Edgar et al., 2011). QIIME was used to cluster reads into operational taxonomical units (OTUs) using the pick_closed_reference_otus.py command. The final OTU table contained between 2329 and 43269 reads for each sample. The varying sequence coverage among samples was adjusted by normalizing the OTU matrix to the same total abundance of sequences for each sample (2329) using the command normalize_table.py in QIIME. Sequences were clustered into OTUs based on at least $97 \%$ sequence similarity, and assigned taxonomical identification against the Greengenes bacterial database (McDonald et al., 2012). The result was a biom-format file containing the taxonomic information for each OTU as well as OTU frequency per sample. Sequence data are available from the NCBI under project ID PRJNA341831, and individual accession numbers are provided in the Supplement.

The carbon contents in the year 0 soils were analysed with a Carlo Erba elemental analyser (NC2500) at the German Research Centre for Geosciences, Potsdam, Germany. The soils were oven-dried at $40^{\circ} \mathrm{C}$ for $48 \mathrm{~h}$, sieved to $<7 \mathrm{~mm}$, and crushed using a TEMA disc mill to achieve size fractions of $<20 \mu \mathrm{m}$. Total organic carbon (TOC) was analysed after reacting the powders with a $10 \% \mathrm{HCl}$ solution for $12 \mathrm{~h}$ to remove inorganic carbonates.

\subsection{Determination of maximum growth rates}

The microbial activity was determined in 113-year-old soil samples after they were thawed (in the dark at $5{ }^{\circ} \mathrm{C}$ to mimic typical field temperature) for $168 \mathrm{~h}$. This age was chosen because these soil samples were assumed to be the ones with the highest microbial biomass and activity and thus the most practical for all laboratory measurements. In order to mitigate the effect of variability derived from differences in soil properties between soil ages (that will later be predicted by the model), laboratory experiments were conducted on a single soil age, with replicate incubations to assess the possible variability in rates (and thus parameter values) that can be attributed to experimental procedures and measurement techniques.

Aliquots of the soils were divided into Petri dishes ( $25 \mathrm{~g}$ of soil (wet weight) into each Petri dish) for subsequent treatments. In order to alleviate nutrient limitations and measure maximum growth rates, four different nutrient conditions were simulated: (1) no addition of nutrients, (2) low $\left(0.03 \mathrm{~m} \mathrm{Cg} \mathrm{g}^{-1}, 0.008 \mathrm{mg} \mathrm{Ng}^{-1}, 0.02 \mathrm{mg} \mathrm{Pg}^{-1}\right)$, (3) medium $\left(0.8 \mathrm{mg} \mathrm{Cg}^{-1}, 0.015 \mathrm{mg} \mathrm{N} \mathrm{g}^{-1}, 0.1 \mathrm{mg} \mathrm{Pg}^{-1}\right)$, and (4) high additions $\left(2.4 \mathrm{mg} \mathrm{g} \mathrm{g}^{-1}, 0.024 \mathrm{mg} \mathrm{g} \mathrm{g}^{-1}\right.$, $\left.0.3 \mathrm{mg} \mathrm{P} \mathrm{g}^{-1}\right)$. The ranges and concentrations were informed by similar experiments in recently exposed proglacial soils at the Damma Glacier, Switzerland (Goransson et al., 2011). Nutrients $\left(\mathrm{C}_{6} \mathrm{H}_{12} \mathrm{O}_{6}\right.$ for $\mathrm{C}, \mathrm{NH}_{4} \mathrm{NO}_{3}$ for $\mathrm{N}$, and $\mathrm{KH}_{2} \mathrm{PO}_{4}$ for $\mathrm{P}$; Sigma, quality $\geq 99.0 \%$ ) were dissolved in $2 \mathrm{~mL}$ of Milli-Q water ( $0.2 \mu \mathrm{m}$ filtered), and mixed into the soils using an ethanol-sterilized spatula. Samples were incubated in the dark for a further $72 \mathrm{~h}$ with the lids on at $25^{\circ} \mathrm{C}$, the reference temperature $\left(T_{\text {ref }}\right)$ at which all rates are defined in SHIMMER prior to adjustment with the temperature dependency expression (using $Q_{10}$; Bradley et al., 2015). In order to de- 
rive a value for $I_{\operatorname{maxH}}$, we were obligated to perform growth incubations at $T_{\text {ref }}\left(25^{\circ} \mathrm{C}\right)$ despite this being a more typical soil temperature of Alpine soils rather than High Arctic soils (see Fig. S3c). However, we are confident that by deriving a $Q_{10}$ value based on incubations of the same soils encapsulating typical $\left(5^{\circ} \mathrm{C}\right)$ to high $\left(25^{\circ} \mathrm{C}\right)$ soil temperatures, we can numerically derive appropriate actual growth rates from the maximum growth rate (at $T_{\text {ref }}$ ). We are confident that the major outcomes and conclusions of this study are not affected by high incubation temperatures since measured growth rates at high temperatures are appropriately scaled using the $Q_{10}$ formulation as measured experimentally. Throughout the whole incubation time, at $24 \mathrm{~h}$ intervals, additional $2 \mathrm{~mL}$ aliquots of Milli-Q water $(0.2 \mu \mathrm{m}$ filtered) were added to maintain approximate soil moisture conditions in each sample.

In these samples bacterial production was estimated by the incorporation of ${ }^{3} \mathrm{H}$-leucine using the microcentrifuge method detailed in Kirchman (2001). After the initial $72 \mathrm{~h}$ incubation period, quadruplicate sample aliquots from the Petri dish incubations and two trichloroacetic acid (TCA)killed control samples were incubated for $3 \mathrm{~h}$ at $T_{\text {ref }}\left(25^{\circ} \mathrm{C}\right)$ for every nutrient treatment. Approximately $50 \mathrm{mg}$ of soil was transferred to sterile microcentrifuge tubes $(2.0 \mathrm{~mL}$, Fisher Scientific). Milli-Q $(0.2 \mu \mathrm{m}$ pre-filtered) water and ${ }^{3} \mathrm{H}$-leucine was added to a final concentration of $100 \mathrm{nM}$ (optimum leucine concentration was pre-determined by a saturation experiment, Fig. S1, Supplement). The incubation was terminated by the addition of TCA to each tube. Tubes were then centrifuged at $15000 \mathrm{~g}$ for $15 \mathrm{~min}$, the supernatant was aspirated with a sterile pipette and removed, and $1 \mathrm{~mL}$ of ice-cold $5 \%$ TCA was added to each tube. Tubes were then centrifuged again at $15000 \mathrm{~g}$ for $5 \mathrm{~min}$, before again aspirating and removing the supernatant. One millilitre of icecold $80 \%$ ethanol was added and tubes were centrifuged at $15000 \mathrm{~g}$ for $5 \mathrm{~min}$, before the supernatant was aspirated and removed again and tubes were left to air-dry for $12 \mathrm{~h}$. Finally, $1 \mathrm{~mL}$ of scintillation cocktail was added and samples were vortexed and then counted by liquid scintillation (Perkin Elmer liquid scintillation analyser, Tri-Carb 2810 TR). Radioisotope activity of TCA-killed control samples was always less than $1.1 \%$ of the measured activity in live samples. There was a positive correlation between the amount of sediment added to the tubes and background counts representing disintegrations per minute (DPM). Counts were individually normalized by the amount of sediment (corrected for dry weight) used in each sample to discount for background DPM. Leucine incorporation rates were converted into bacterial carbon production following the methodology of Simon and Azam (1989). Bacterial abundance was estimated from each treatment after the $72 \mathrm{~h}$ incubation period by microscopy. Five samples from each Petri dish were counted for each nutrient treatment with negative controls yielding no detectable cells. One-way ANOVA (with post hoc Tukey HSD) statistical tests were used for evaluations of the variability from the multiple treatments.

\subsection{Temperature response}

Microbial community respiration was determined by measuring $\mathrm{CO}_{2}$ gas exchange rates in airtight incubation vials. Soil samples from the 113-year-old site were defrosted and divided ( $25 \mathrm{~g}$ wet weight) in Petri dishes as above, and $2 \mathrm{~mL}$ of Milli-Q water $(0.2 \mu \mathrm{m}$ filtered) was added (to maintain consistency of soil moisture with determination of bacterial production above). Samples were incubated at $5{ }^{\circ} \mathrm{C}\left(T_{1}\right)$ and $25^{\circ} \mathrm{C}\left(T_{2}\right)$ in the dark for a further $72 \mathrm{~h}$. Two millilitres of $0.2 \mu \mathrm{m}$ pre-filtered Milli-Q water was added to the $T_{1}$ sample $\left(3 \mathrm{~mL}\right.$ for $\left.T_{2}\right)$ at 24,48 , and $72 \mathrm{~h}$ to maintain approximate soil moisture content. Two separate killed control tests (one furnaced at $450{ }^{\circ} \mathrm{C}$ for $4 \mathrm{~h}$ and one autoclaved; three cycles at $121^{\circ} \mathrm{C}$ ) were incubated at $T_{1}$ and $T_{2}$. Quintuple live and killed samples (roughly $1 \mathrm{~g}$ ) were transferred into cleaned $20 \mathrm{~mL}$ glass vials (rinsed in $2 \%$ Decon, submersed in $10 \% \mathrm{HCl}$ for $24 \mathrm{~h}$, rinsed three times with Milli-Q water, and furnaced at $450^{\circ} \mathrm{C}$ for $\left.4 \mathrm{~h}\right)$. These were sealed $\left(9^{\circ} \mathrm{C}\right.$, atmospheric pressure, ambient $\mathrm{CO}_{2}$ of $405 \mathrm{ppm}$ ) with presterilized Bellco butyl stoppers (pre-sterilized by boiling for $4 \mathrm{~h}$ in $1 \mathrm{M}$ sodium hydroxide) and crimped shut with aluminium caps. Sealed vials were then incubated at $T_{1}$ and $T_{2}$ for $24 \mathrm{~h}$ in darkness. After $24 \mathrm{~h}$, the headspace gas was removed with a gas-tight syringe and immediately analysed on an EGM4 gas analyser (PP Systems, calibrated using gas standards matching the expected range, precision $1.9 \%$, $2 \times \mathrm{SE}$ ). Empty pre-sterilized vials were also incubated and analysed. Following gas analysis, vials were opened and dried to a constant weight at $105^{\circ} \mathrm{C}$ to estimate moisture content and thus dry soil weight of these aliquots. Headspace $\mathrm{CO}_{2}$ change (ppm) was converted to microbial respiration using the ideal gas law ( $n=\mathrm{PV} / \mathrm{RT})$, assuming negligible changes in soil pore water $\mathrm{pH}$ (and therefore $\mathrm{CO}_{2}$ solubility) during the incubation. $\mathrm{CO}_{2}$ headspace changes resulting from killed controls and blanks were $<70 \%$ of the changes resulting from the incubations at $T_{1}$ and $<7 \%$ of the changes observed at $T_{2}$. One-way ANOVA (with post hoc Tukey HSD) statistical tests were used for comparison of multiple treatments. No significant differences in $\mathrm{CO}_{2}$ headspace change between killed controls at $T_{1}$ and $T_{2}$ were detected $(P=0.95)$.

\subsection{Microbial model: SHIMMER}

SHIMMER (Bradley et al., 2015) mechanistically describes and predicts transformations in carbon, nitrogen, and phosphorus through aggregated components of the microbial community as a system of interlinked ordinary differential equations. The model contains pools of microbial biomass, organic matter, and both dissolved inorganic and organic nitrogen and phosphorus (Table 1). It categorizes microbes into autotrophs $\left(A_{1-3}\right)$ and heterotrophs $\left(H_{1-3}\right)$, and further subdivides these based on three specific functional traits. Microbes derived from underneath the glacier (referred to as 
Table 1. State variables and initial values.

\begin{tabular}{|c|c|c|c|}
\hline $\begin{array}{l}\text { State } \\
\text { variable }\end{array}$ & Units & Description & $\begin{array}{r}\text { Initial value } \\
(\text { year } 0) \\
\left(\mu \mathrm{gg}^{-1}\right)\end{array}$ \\
\hline$A_{1}$ & $\mu \mathrm{g} \mathrm{Cg}^{-1}$ & Glacial chemolithoautotrophs & 0.0547 \\
\hline$A_{2}$ & $\mu \mathrm{g} \mathrm{Cg}^{-1}$ & Soil autotrophs & 0.0266 \\
\hline$A_{3}$ & $\mu \mathrm{g} \mathrm{Cg}^{-1}$ & Nitrogen-fixing soil autotrophs & 0.0355 \\
\hline$H_{1}$ & $\mu \mathrm{g} \mathrm{Cg}-1$ & Glacial heterotrophs & 0.0576 \\
\hline $\mathrm{H}_{2}$ & $\mu \mathrm{g} \mathrm{Cg}^{-1}$ & Soil heterotrophs & 0.0530 \\
\hline $\mathrm{H}_{3}$ & $\mu \mathrm{g} \mathrm{Cg}^{-1}$ & Nitrogen-fixing soil heterotrophs & 0.0025 \\
\hline$S_{1}$ & $\mu \mathrm{g} \mathrm{Cg}^{-1}$ & Labile organic carbon & 291.895 \\
\hline$S_{2}$ & $\mu \mathrm{g} \mathrm{Cg}^{-1}$ & Refractory organic carbon & 681.089 \\
\hline DIN & $\mu g \mathrm{Ng}^{-1}$ & Dissolved inorganic nitrogen (DIN) & 3.530 \\
\hline DIP & $\mu \mathrm{g} \mathrm{Pg}^{-1}$ & Dissolved inorganic phosphorus (DIP) & 2.078 \\
\hline $\mathrm{ON}_{1}$ & $\mu \mathrm{g} \mathrm{Ng}^{-1}$ & Labile organic nitrogen & 41.157 \\
\hline $\mathrm{ON}_{2}$ & $\mu g \mathrm{Ng}^{-1}$ & Refractory organic nitrogen & 96.034 \\
\hline $\mathrm{OP}_{1}$ & $\mu \mathrm{P} \mathrm{g}^{-1}$ & Labile organic phosphorus & 24.227 \\
\hline $\mathrm{OP}_{2}$ & $\mu \mathrm{g} \mathrm{Pg}^{-1}$ & Refractory organic phosphorus & 56.530 \\
\hline
\end{tabular}

"glacial microbes") are termed $A_{1}$ and $H_{1} . A_{1}$ microbes are chemolithoautotrophic, obtaining energy from the oxidation and reduction of inorganic compounds and carbon from the fixation of carbon dioxide. In contrast, $H_{1}$ microbes rely on the breakdown of organic molecules for energy to support growth. $\mathrm{A}_{2}$ and $\mathrm{H}_{2}$ represent autotrophic and heterotrophic microbes commonly found in glacier forefield soils with no "special" characteristics, and will be referred to as "soil microbes". $\mathrm{A}_{3}$ and $\mathrm{H}_{3}$ are autotrophs and heterotrophs that are able to fix atmospheric $\mathrm{N}_{2}$ gas as a source of nitrogen in cases when dissolved inorganic nitrogen (DIN) stocks become limiting. Available organic substrate is assumed to be derived naturally from dead organic matter and allochthonous inputs. Labile compounds are immediately available fresh and highly reactive material, rapidly turned over by the microorganisms $\left(S_{1}, \mathrm{ON}_{1}, \mathrm{OP}_{1}\right)$. Refractory compounds are less bioavailable and represent the bulk of substrate present in the non-living organic component of soil $\left(\mathrm{S}_{2}, \mathrm{ON}_{2}, \mathrm{OP}_{2}\right)$. A conceptual diagram showing the components and transfers of SHIMMER is presented in the Supplement (Fig. S2).

Microbial biomass responds dynamically to changing substrate and nutrient availability (expressed as Monod kinetics), as well as changing environmental conditions (such as temperature and light). A $Q_{10}$ temperature response function $\left(T_{\mathrm{f}}\right)$ is affixed to all metabolic processes including growth rates and death rates (Bradley et al., 2015), thus effectively slowing down or speeding up all life processes as temperature changes (Soetaert and Herman, 2009; Yoshitake et al., 2010; Schipper et al., 2014). Light limitation is expressed as Monod kinetics. The following external forcings drive and regulate the system's dynamics:

- photosynthetically active radiation (PAR; wavelength of approximately 400 to $700 \mathrm{~nm} ; \mathrm{W} \mathrm{m}^{-2}$ ),
- snow depth (m),

- soil temperature $\left({ }^{\circ} \mathrm{C}\right)$,

- allochthonous inputs $\left(\mu \mathrm{g} \mathrm{g}^{-1} \mathrm{day}^{-1}\right)$.

The model is 0-D and represents the soil as a homogeneous mix. Thus, light, temperature, nutrients, organic compounds, and microbial biomass are assumed to be evenly distributed.

Soil temperature (at $1 \mathrm{~cm}$ depth) for the entire of 2013 is provided by Alfred Wegener Institute for Polar and Marine Research (AWI) from the permafrost observatory near NyÅlesund, Svalbard. Similarly, PAR for 2013 is measured at the AWI surface radiation station near Ny-Ålesund, Svalbard. Averaged daily snow depth for 2009 to 2013 is provided by the Norwegian Meteorological Institute (eKlima). Allochthonous nutrient fluxes (inputs and leaching) are estimated based on an evaluation of nutrient budgets of the Midtre Lovénbreen catchment (Hodson et al., 2005) in which budgets for nutrient deposition rates and runoff concentrations are measured over two full summer-winter seasons and residual retention rates (excess of inputs) or depletion rates (excess of outputs) are inferred. The bioavailability of allochthonous material is assumed to be the same as initial material and microbial necromass.

Initial conditions were informed by analysis of 0-years-ofexposure soil collected adjacent to the ice snout, and initial values for all state variables are presented in Table 1. Initial microbial biomass was estimated by microscopy as described above. Initial community structure was derived by $16 \mathrm{~S}$ analysis of year-0 soils. An initial value for carbon substrate $\left(S_{1}+S_{2}\right)$ was estimated based on the average TOC content of year- 0 soil. Bioavailability of model TOC was assumed to be $30 \%$ labile $\left(S_{1}\right)$ and $70 \%$ refractory $\left(S_{2}\right)$ (for consistency with Bradley et al., 2015). Organic nitrogen (ON) and 
organic phosphorus (OP) were assumed to be stoichiometrically linked by the measured $\mathrm{C}: \mathrm{N}: \mathrm{P}$ ratio from the Damma Glacier forefield (from which the model was initially developed and tested; Bradley et al., 2015). An initial value for DIN was taken from a previous evaluation of Svalbard tundra nitrogen dynamics, whereby the lowest value is taken to represent the soil of least development, according to the traditional understanding of glacier forefields (Alves et al., 2013; Bradley et al., 2014). An initial value for dissolved inorganic phosphorous (DIP) was established stoichiometrically from previous model development and testing.

Model implementation and setup is described in more detail in the Supplement.

\subsection{Model parameters}

Maximum heterotrophic growth rate $I_{\operatorname{maxH}}\left(\right.$ day $\left.^{-1}\right)$ was estimated by scaling the measured rate of bacterial production ( $\mu \mathrm{g} \mathrm{Cg}^{-1} \mathrm{day}^{-1}$; converted to dry weight) with total heterotrophic biomass $\left(\mu \mathrm{g} \mathrm{g} \mathrm{g}^{-1}\right)$. Nutrient addition alleviates growth limitations as defined in SHIMMER (Bradley et al., 2015); thus, bacterial communities can be assumed to be growing at $I_{\mathrm{maxH}}$ under experimental conditions.

$Y_{\mathrm{H}}$ represents heterotrophic BGE and was estimated according to the equation

$Y_{\mathrm{H}}=\frac{\mathrm{BP}}{\mathrm{BP}+\mathrm{BR}}$,

where $\mathrm{BP}$ and $\mathrm{BR}$ are measured bacterial production and measured bacterial respiration $\left(\mu \mathrm{g} \mathrm{Cg}^{-1} \mathrm{day}^{-1}\right)$ respectively at $25^{\circ} \mathrm{C}$ with no nutrients added.

The temperature response $\left(Q_{10}\right)$ value was estimated as

$Q_{10}=\left(\frac{R_{2}}{R_{1}}\right)^{\left(\frac{10}{T_{2}-T_{1}}\right)}$,

where $R_{1}$ and $R_{2}$ represent the measured respiration rate ( $\mu \mathrm{g} \mathrm{C} \mathrm{g}^{-1}$ day $\left.^{-1}\right)$ at temperatures $T_{1}$ and $T_{2}\left(5\right.$ and $\left.25^{\circ} \mathrm{C}\right)$.

Laboratory-defined parameters (i.e. growth rate, temperature sensitivity, and BGE) were assumed to be the same for all microbial groups. A complete list of parameters and values is presented in Table S3 (Supplement).

\section{Results}

\subsection{Laboratory results and model parameters}

Bacterial production in untreated soil was estimated at $0.76 \mu \mathrm{g} \mathrm{C} \mathrm{g}^{-1} \mathrm{day}^{-1} \quad(\mathrm{SD}=0.12)$, and across all nutrient treatments ranged from 0.560 to $2.196 \mu \mathrm{g} \mathrm{Cg}^{-1} \mathrm{day}^{-1}$. Nutrient addition led to increased measured production $\quad\left(\right.$ low $=0.69 \mu \mathrm{g} \mathrm{Cg}^{-1} \mathrm{day}^{-1} \quad(\mathrm{SD}=0.12)$, medium $=1.09 \mu \mathrm{g} \mathrm{C} \mathrm{g}^{-1} \mathrm{day}^{-1} \quad(\mathrm{SD}=0.53), \quad$ and high $\left.=1.52 \mu \mathrm{g} \mathrm{C} \mathrm{g}^{-1} \mathrm{day}^{-1} \quad(\mathrm{SD}=0.63)\right)$; however, variability between replicates was also high and production (a)
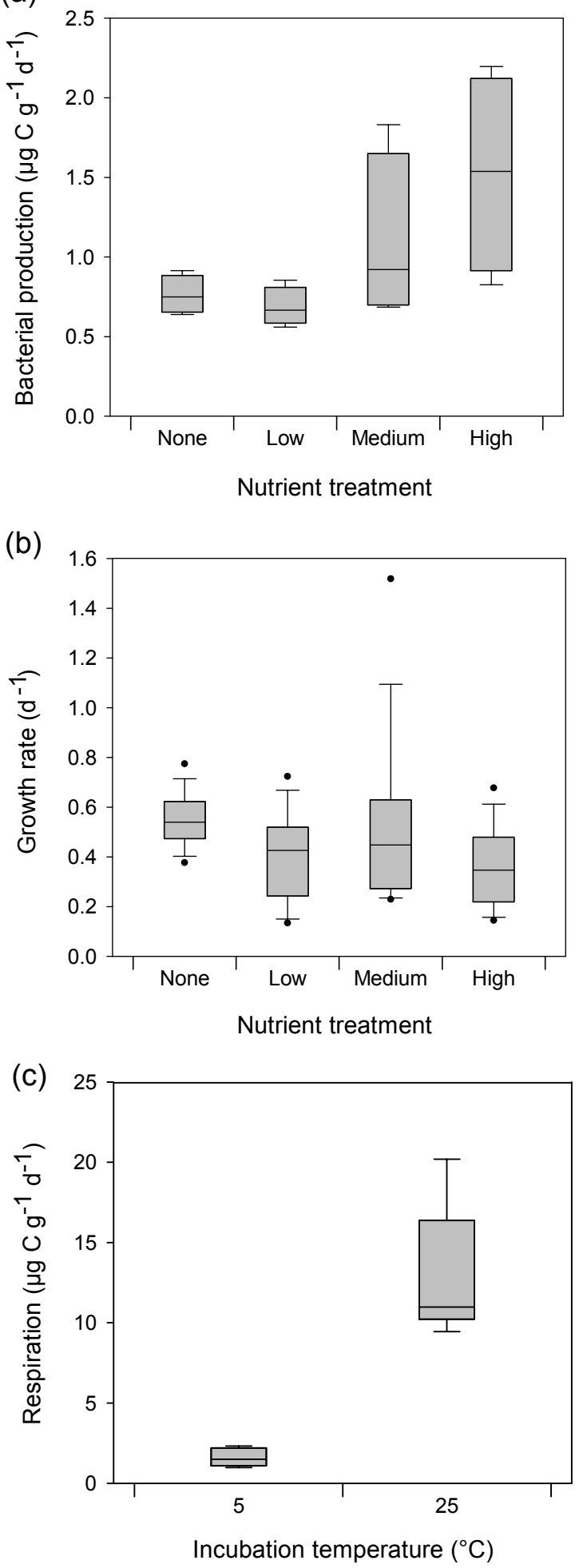

Figure 2. Measurements of (a) bacterial carbon production and (b) growth rate, derived from ${ }^{3} \mathrm{H}$-leucine assays at different nutrient conditions, and (c) bacterial respiration at 5 and $25^{\circ} \mathrm{C}$. 
Table 2. Microbial biomass in the forefield of Midtre Lovénbreen (brackets show 1 standard deviation).

\begin{tabular}{lrrr}
\hline $\begin{array}{l}\text { Soil age } \\
\text { (years) }\end{array}$ & $\begin{array}{r}\text { Autotrophic } \\
\text { biomass }\left(\mu \mathrm{gg}^{-1}\right)\end{array}$ & $\begin{array}{r}\text { Heterotrophic } \\
\text { biomass }\left(\mu \mathrm{Cg}^{-1}\right)\end{array}$ & $\begin{array}{r}\text { Total organic } \\
\text { carbon }\left(\mu \mathrm{g} \mathrm{g}^{-1}\right)\end{array}$ \\
\hline 0 & $0.171(0.042)$ & $0.059(0.034)$ & $792.984(127.206)$ \\
3 & $0.287(0.155)$ & $0.064(0.029)$ & \\
5 & $0.561(0.143)$ & $0.083(0.065)$ & \\
29 & $1.072(0.487)$ & $0.244(0.142)$ & \\
50 & $1.497(0.601)$ & $0.197(0.184)$ & \\
113 & $2.581(0.927)$ & $2.000(0.885)$ & \\
\hline
\end{tabular}

rates from each nutrient treatment were not significantly different from untreated soil $\left(P_{\text {low }}=0.99, P_{\text {medium }}=0.70\right.$, $\left.P_{\text {high }}=0.10\right)$. The increased bacterial production was crosscorrelated with quadruplicate measurements of biomass from each treatment, and resulting growth rate coefficients $\left(I_{\operatorname{maxH}}\right)$ for all treatments were within a narrow range $(0.359$ to $0.550 \mathrm{day}^{-1}$ ) and there was no statistically significant difference in growth rates between each nutrient treatment (Fig. 2b) $\left(P_{\text {low-medium }}=0.55, \quad P_{\text {medium-high }}=0.49\right.$, $\left.P_{\text {none-high }}=0.10\right)$. The maximum measured growth rate for a single nutrient treatment, thus equating to the parameter $I_{\operatorname{maxH}}$, was $0.55 \mathrm{day}^{-1}$. The $95 \%$ confidence range for $I_{\operatorname{maxH}}$ is 0.50 to $0.60 \mathrm{day}^{-1}$. This value is, to our knowledge, the first measured rate of bacterial growth from High Arctic soils, and falls within the lower end of the plausible range established in Bradley et al. (2015; 0.24-4.80 day ${ }^{-1}$; Fig. 3a) for soil microbes from a range of laboratory and modelling studies (Frey et al., 2010; Ingwersen et al., 2008; Knapp et al., 1983; Zelenev et al., 2000; Stapleton et al., 2005; Darrah, 1991; Blagodatsky et al., 1998; Vandewerf and Verstraete, 1987; Foereid and Yearsley, 2004; Toal et al., 2000; Scott et al., 1995). For respiration, significantly higher $\mathrm{CO}_{2}$ headspace concentrations were detected in the live incubations at $25^{\circ} \mathrm{C}$ relative to killed controls $(P<0.05)$. Average respiration rate at $5^{\circ} \mathrm{C}$ was $1.61 \mu \mathrm{g} \mathrm{g} \mathrm{g}^{-1} \mathrm{day}^{-1}$ and there was a significant increase in soil respiration at $25^{\circ} \mathrm{C}$ (12.83 $\mathrm{g} \mathrm{C} \mathrm{g}^{-1} \mathrm{day}^{-1}$; Fig. 2c; $\left.P<0.05\right)$. The $Q_{10}$ value for Midtre Lovénbreen forefield soils was thus calculated as 2.90, and a $95 \%$ confidence range was established as 2.65 to 3.16. This was at the upper end of the plausible range previously identified in Bradley et al. (2015; Fig. 3b). Based on measured values of bacterial production and respiration, $\operatorname{BGE}\left(Y_{\mathrm{H}}\right)$ was 0.06 , with a $95 \%$ confidence range of 0.05 to 0.07 (Fig. 3c). Final calculated values for model parameters are summarized in Table S3.

The results from microscopy determination of biomass are presented in Table 2. In the freshly exposed soil (year 0) heterotrophic biomass was low $\left(0.059 \mu \mathrm{g} \mathrm{Cg}^{-1}\right)$, increased substantially to $0.244 \mu \mathrm{g} \mathrm{Cg}^{-1}$ in 29-year-old soils, and was an order or magnitude higher $\left(2.00 \mu \mathrm{g} \mathrm{Cg}^{-1}\right)$ in 113 year-old soils. Autotrophic biomass was considerably higher than heterotrophic biomass and increased by roughly an order of magnitude from year $0\left(0.171 \mu \mathrm{g} \mathrm{Cg}^{-1}\right)$ to year $29\left(1.07 \mu \mathrm{g} \mathrm{Cg}^{-1}\right)$ and approximately doubled again by year $113\left(2.58 \mu \mathrm{g} \mathrm{Cg}^{-1}\right)$. TOC in freshly exposed soil was approximately $0.793 \mathrm{mg} \mathrm{C} \mathrm{g}^{-1}$.

$16 \mathrm{~S}$ data were categorized into microbial groups ( $A_{1-3}$ and $H_{1-3}$ ) as defined by the model formulation. Chemolithoautotrophs, such as known iron or sulfur oxidizers (genera Acidithiobacillus, Thiobacillus, Gallionella, Sulfurimonas) were assigned into the $A_{1}$ group. Phototrophic microorganisms, such as cyanobacteria (Phormidium, Leptolyngbya) and phototrophic bacteria (Rhodoferax, Erythrobacter, Halomicronema), were allocated into group $A_{2}$, while heterocyst-forming cyanobacteria from the orders Nostocales and Stigonematales were assigned to group $A_{3}$ (nitrogen-fixing autotrophs). Members of the family Comamonadaceae of the Betaproteobacteria are known glacierdwelling microorganisms (Yde et al., 2010) and were thus included into the group $H_{1}$. General soil heterotrophic microorganisms (mainly members of Alphaproteobacteria, Actinobacteria, Bacterioidetes, and Acidobacteria) were assigned into group $\mathrm{H}_{2}$ (general soil heterotrophs). Lastly, group $\mathrm{H}_{3}$ consisted of heterotrophic nitrogen fixers, mainly Azospirillum, Bradyrhizobium, Devosia, Clostridium, Frankia, and Rhizobium. Pathogens, non-soil microorganisms, and organisms with unknown physiological traits were assigned into the "uncategorized" group. Glacial microbes accounted for 43 to $45 \%$ of reads in year 0 and 5 and declined in older soils (year 50 and 113 ) to 18 to $22 \%$. The glacial community was predominantly chemolithoautotrophic $\left(A_{1}\right)$. Typical soil bacteria $\left(\mathrm{A}_{2}\right.$ and $\left.\mathrm{H}_{2}\right)$ increased from low abundance (30 and $40 \%$ in years 0 and 5 respectively) to relatively high abundance (63 to $67 \%$ of reads) in years 50 and 113 . Nitrogenfixing bacteria were prevalent in recently exposed soils (14\% in year 0) but low in relative abundance in soils above 5 years of age ( 4 to $6 \%$ in years 5,50 , and 113). In the freshly exposed soil (year 0 ), the microbial community was relatively evenly distributed between heterotrophs (43\%) and autotrophs (44\%). In developed soils, the relative abundance of heterotrophs increased (up to $74 \%$ of reads in years 50 and 113). Important to note is the fact that between 8 and $21 \%$ of the reads across all samples could not be classified.

\subsection{Model results}

The model predicted an accumulation of autotrophic and heterotrophic biomass over 120 years (Fig. 4a and b). Biomass and nutrient concentrations were initially extremely low (total biomass $<0.25 \mu \mathrm{g} \mathrm{C} \mathrm{g}^{-1}$, DIN $<4.0 \mu \mathrm{g} \mathrm{N} \mathrm{g}^{-1}$, DIP $<3.0 \mu \mathrm{g} \mathrm{P} \mathrm{g}^{-1}$ ), and biological activity in initial soils was also low (Table 3). There was an order of magnitude increase in total microbial biomass in years 10 to 60 . Nitrogenfixing autotrophs $\left(A_{3}\right)$ and heterotrophs $\left(H_{3}\right)$, as well as soil heterotrophs $\left(\mathrm{H}_{2}\right)$, experienced rapid growth during this period. Glacial and soil autotrophs $\left(A_{1-2}\right)$ and glacial heterotrophs $\left(H_{1}\right)$ remained low. Bacterial production increased by roughly 2 orders of magnitude (Table 3 ). Organic car- 
(a)

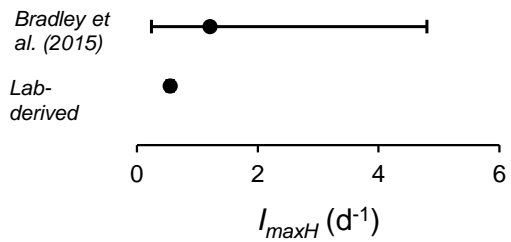

(b)

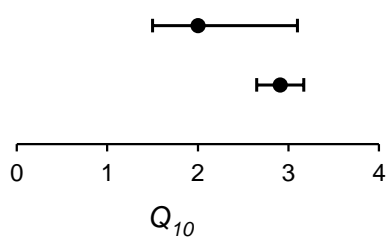

(c)

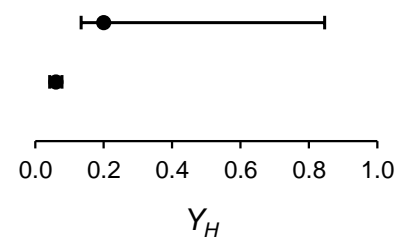

Figure 3. A comparison of previously established ranges for parameters (Bradley et al., 2015) with laboratory-derived values for (a) maximum growth rate $\left(I_{\max }\right)$, (b) temperature response $\left(Q_{10}\right)$, and $(\mathbf{c}) \operatorname{BGE}\left(Y_{\mathrm{H}}\right)$.

(a)

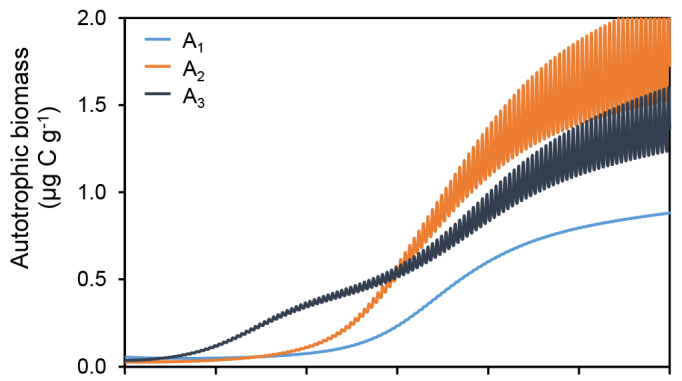

(c)
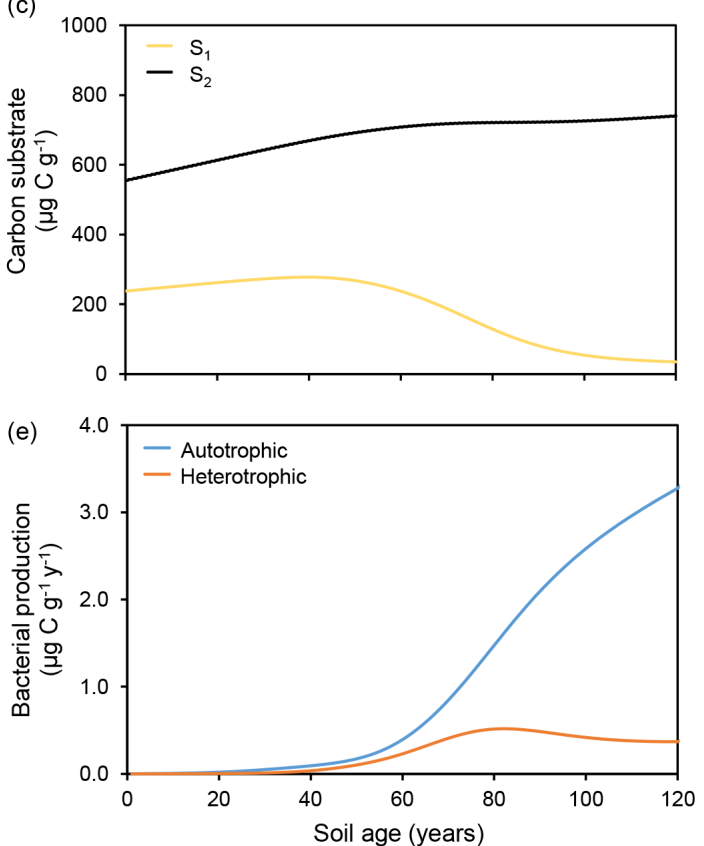

(b)
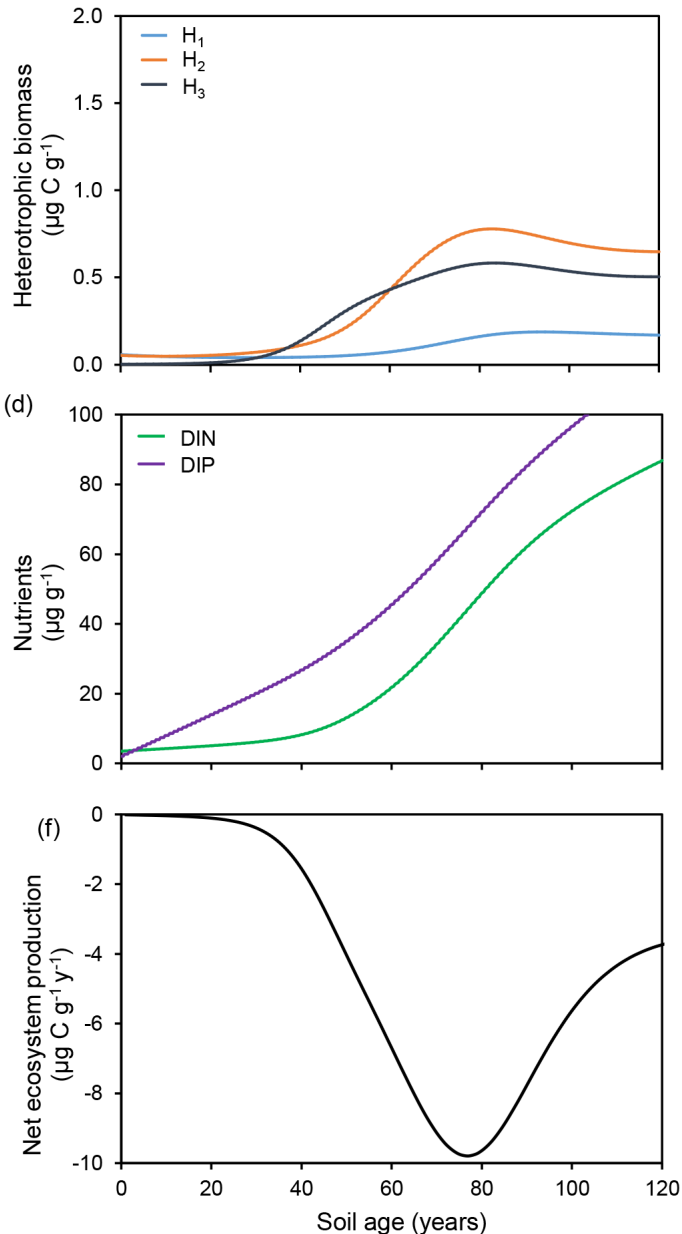

Figure 4. Modelled (a) autotrophic biomass, (b) heterotrophic biomass, (c) carbon substrate, (d) nutrients, (e) bacterial production, and (f) net ecosystem production, with laboratory-derived parameter values.

bon (labile and refractory) increased (Fig. 4c), whilst DIN and DIP concentrations increased by approximately an order of magnitude in the first 60 years (Fig. 4d). During the later stages of soil development (years 60 to 120), biomass increased rapidly due to the rapid growth of soil organisms $\left(A_{2}\right.$ and $H_{2}$ ), which outcompeted nitrogen fixers. The model showed a rapid exhaustion of labile organic carbon (years
50 to 100), while refractory carbon accumulated slowly. $\mathrm{Nu}-$ trients (DIN and DIP) accumulated at a relatively constant rate. Microbial activity, including bacterial production, nitrogen fixation, and DIN assimilation, was high relative to early stages (Table 3).

A carbon budget of fluxes through the substrate pool is presented in Fig. 5. Daily fluxes are presented in panels (a) 
Table 3. Model output.

\begin{tabular}{|c|c|c|c|c|c|c|c|}
\hline $\begin{array}{l}\text { Soil } \\
\text { Age } \\
\text { (years) }\end{array}$ & $\begin{array}{r}\text { Autotrophic } \\
\text { biomass } \\
\left(\mu \mathrm{g} \mathrm{Cg}^{-1}\right)\end{array}$ & $\begin{array}{r}\text { Heterotrophic } \\
\text { biomass } \\
\left(\mu \mathrm{g} \mathrm{Cg}^{-1}\right)\end{array}$ & $\begin{array}{r}\text { Autotrophic } \\
\text { production } \\
\left(\mu \mathrm{g} \mathrm{Cg}^{-1} \mathrm{yr}^{-1}\right)\end{array}$ & $\begin{array}{r}\text { Heterotrophic } \\
\text { production } \\
\left(\mu \mathrm{g} \mathrm{Cg}^{-1} \mathrm{yr}^{-1}\right)\end{array}$ & $\begin{array}{r}\text { Net ecosystem } \\
\text { production } \\
\left(\mu \mathrm{g} \mathrm{Cg}^{-1} \mathrm{yr}^{-1}\right)\end{array}$ & $\begin{array}{r}\text { DIN } \\
\text { assimilation } \\
\left(\mu \mathrm{g} \mathrm{Ng}^{-1} \mathrm{yr}^{-1}\right)\end{array}$ & $\begin{array}{r}\mathrm{N}_{2} \\
\text { fixation } \\
\left(\mu \mathrm{g} \mathrm{Ng}^{-1} \mathrm{yr}^{-1}\right)\end{array}$ \\
\hline 0 & 0.117 & 0.111 & 0.002 & 0.001 & -0.011 & $2.0 \times 10^{-4}$ & $2.0 \times 10^{-4}$ \\
\hline 3 & 0.117 & 0.105 & 0.003 & 0.001 & -0.020 & $3.0 \times 10^{-4}$ & $3.0 \times 10^{-4}$ \\
\hline 5 & 0.119 & 0.102 & 0.004 & 0.001 & -0.025 & $4.0 \times 10^{-4}$ & $4.0 \times 10^{-4}$ \\
\hline 29 & 0.359 & 0.147 & 0.050 & 0.012 & -0.391 & 0.002 & 0.006 \\
\hline 50 & 0.860 & 0.591 & 0.187 & 0.113 & -4.311 & 0.022 & 0.021 \\
\hline 113 & 4.414 & 1.331 & 3.093 & 0.376 & -4.031 & 0.458 & 0.031 \\
\hline
\end{tabular}

for year 5, (b) for year 50, and (c) for year 113, and annual fluxes up to year 120 are presented in (d). In recently exposed soils (5 years), allochthonous inputs were the only noticeable carbon flux, outweighing heterotrophic growth and respiration as well as and the contribution of substrate from necromass and exudates by over 2 orders of magnitude (Fig. 5a). Thus, the total change in carbon (black line) closely resembled allochthonous input. In the intermediate stages (Fig. 5b), there was substantial depletion from the substrate pool due to heterotrophic activity. Heterotrophic growth (red line) was low despite high substrate consumption and respiration (dark blue line). In the late stages of soil development, the flux of microbial necromass was a significant contributor to the organic substrate pools (Fig. 5c). Carbon fluxes in the middle to late stages of soil development were highly seasonal (Fig. 5b and c). Biotic fluxes (e.g. respiration) were up to 6 times higher during the summer (July to September) compared to the winter (November to April); however, a base rate of heterotrophic respiration and turnover of microbial biomass was sustained over winter. Figure 5d shows that the contribution of microbial necromass rose steadily throughout the simulation (light blue line) but was not sufficient to compensate for the uptake of carbon substrate, thus leading to overall depletion between years 50 and 110 (black line). The contribution of exudates (purple line) to substrate was minimal at all soil ages.

\section{Discussion}

\subsection{Determination of parameters and model predictions}

Figure 6 illustrates the influence of the site-specific, laboratory-derived parameters on microbial biomass predictions. It compares the range of predicted microbial biomass based on laboratory-determined parameters (yellow) to the entire plausible parameter range (red; Bradley et al., 2015). Predicted biomass with the average laboratory-derived value is indicated by the black line. For $I_{\max }$, predicted biomass with laboratory-derived parameters (yellow shading) was towards the lower end of the plausible range (Fig. 6a) because refined growth rates were significantly lower than the maximum values explored previously. This was mostly due to a significant reduction in autotrophic biomass $\left(A_{1-3}\right)$. With high growth rates, there was a sharp early increase in biomass (years 10 to 20) followed by a slower growth phase (years 20 to 120). Model results with laboratory-derived growth rates showed that the exponential growth phase occurred later (years 40 to 80 ) and was more prolonged, but total biomass was considerably lower.

There was a substantial reduction in the plausible range in predicted microbial biomass (Fig. 6b) from the measured temperature sensitivity ( $Q_{10}$; yellow) compared to the previous range (red). Soil microbial communities in polar regions must contend with extremely harsh environmental conditions such as cold temperatures, frequent freeze-thaw cycles, low water availability, low nutrient availability, high exposure to ultraviolet radiation in the summer, and prolonged periods of darkness in winter. These factors profoundly impact their metabolism and survival strategies and ultimately shape the structure of the microbial community (Cary et al., 2010). High $Q_{10}$ values, as derived here, are typical of cold environments and cold-adapted organisms, and this has been associated with the survival of biomass under prolonged periods of harsh environmental conditions (Schipper et al., 2014). An investigation into the metabolism of microbial communities in biological soils crusts in recently exposed soils from Austre Brøggerbreen, approximately $6 \mathrm{~km}$ from the Midtre Lovénbreen catchment, also derived a high $Q_{10}$ (3.1; Yoshitake et al., 2010). The Midtre Lovénbreen catchment, in Svalbard, experiences a relatively extreme Arctic climate. The high $Q_{10}$ ultimately lowers the overall rate of biomass accumulation in ultra-oligotrophic soils and a baseline population is maintained.

The low measured BGE (0.06) suggested that a high proportion $(94 \%)$ of substrate consumed by heterotrophs is remineralized (degrading organic substrate into DIC $\left(\mathrm{CO}_{2}\right)$, DIN, and DIP), with very little being incorporated into biomass $(6 \%)$. Low BGE encouraged the liberation and release of nutrients to the soil and thus the overall growth response of the total microbial biomass was more rapid due to higher soil nutrient concentrations (Fig. 6c). However, due to the low BGE, there was a high rate of substrate 
(a)

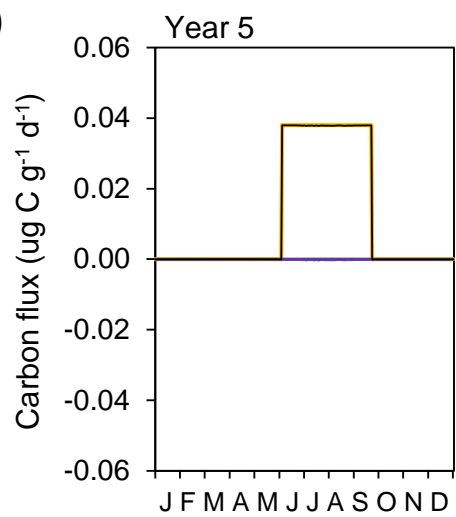

(b)

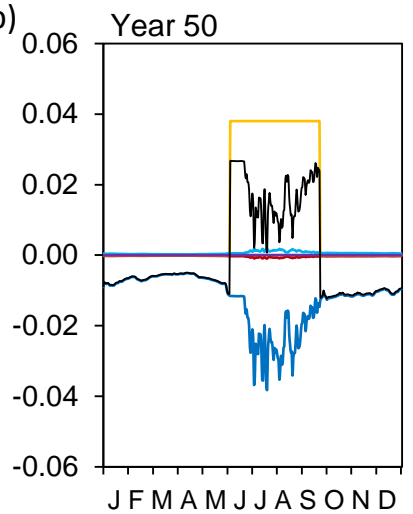

(c)

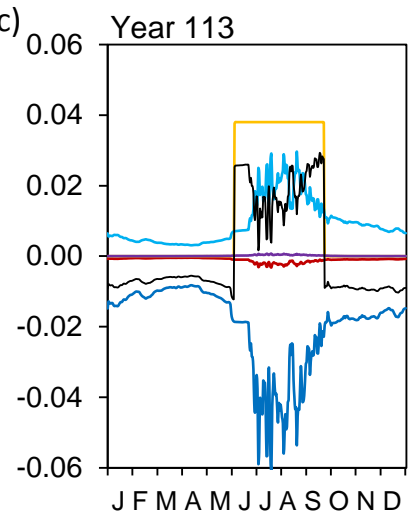

(d)

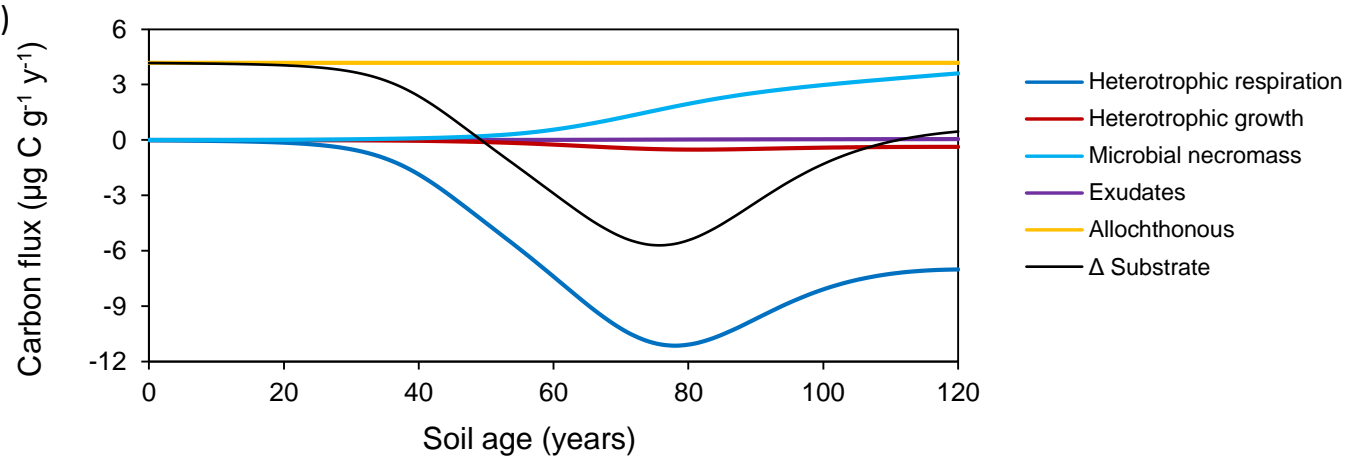

Figure 5. Illustration of daily carbon fluxes for (a) 5-, (b) 50-, and (c) 113-year-old soil, as well as (d) annual carbon flux over 120 years. Microbial necromass (light blue), exudates (purple), and allochthonous sources (yellow) contribute to the substrate pool (black), and heterotrophic growth (red) and respiration (dark blue) deplete it.

degradation, and as such labile substrate was rapidly depleted when heterotrophic biomass was high (Fig. 4c). Heterotrophic growth requires that a substantial amount of substrate is degraded - thus, although autotrophic production outweighed heterotrophic production at all stages of development (Fig. 4e), the soil was predicted by the model to be a net source of $\mathrm{CO}_{2}$ to the atmosphere over the first 120 years of exposure (Fig. 4f). Heterotrophic growth and respiration (and thus net ecosystem production and carbon fluxes) are strongly dependent on the availability of soil organic carbon. Poorly quantified rates of allochthonous organic carbon deposition and its quality may lead to generally high uncertainty in the net ecosystem production due to potentially enhanced heterotrophic growth resulting from higher organic carbon deposition, or lower heterotrophic growth resulting from substrate limitation in low-deposition scenarios. Soil $\mathrm{CO}_{2}$ efflux is highly sensitive to variable net ecosystem production; thus, simulated net ecosystem production estimates must be interpreted cautiously until sufficient field data emerge (e.g. from in situ measurement of soil gas exchange). The calculation of BGE assumes that bacterial respiration is the major contributor to measured $\mathrm{CO}_{2}$ gas exchange rates from soil microcosms. In reality, all active and living soil organisms are likely to contribute to measured $\mathrm{CO}_{2}$ fluxes; however, due to limitations with experimental protocols, it is extremely difficult to determine the relative contribution of various organisms to total respiration. Microscopy analysis showed the limited presence of fungi and protozoa, suggesting that the biological community of the soil is mainly bacterial. Nevertheless, by attributing total measured $\mathrm{CO}_{2}$ fluxes solely to bacteria, BGE may be underestimated (due to an overestimation of respiration rates attributed to the bacterial community). Thus, we cannot exclude that our low BGE values might be in part an artefact of this experimental limitation. However, although there are very few measurements of BGE in cold glaciated environments, our estimate of BGE is in good agreement with previous studies, which have suggested values ranging between 0.0035 and 0.033 (Anesio et al., 2010; Hodson et al., 2007). Therefore, we are confident that BGE values measured here fall within a realistic range.

Three assumptions are made in the assignment of measured parameters to SHIMMER as applied to the High Arctic field site. The first assumption of SHIMMER is that parameter values remain constant throughout the duration of the simulation. Empirical evidence suggests that parameters defined as fixed in SHIMMER (e.g. $Q_{10}$ ) may be variable over time; however, in SHIMMER, like many numerical modelling formulations, changing environmental (temperature, light) and geochemical (carbon substrate, available nitrogen, available phosphorus) conditions drive subsequent variabil- 
(a)

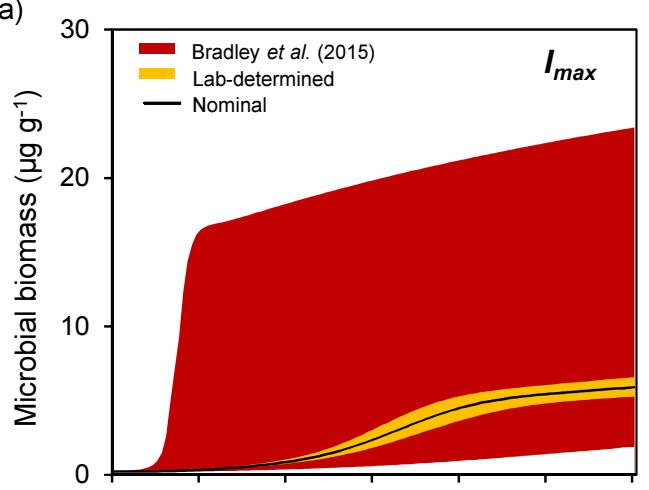

(b)

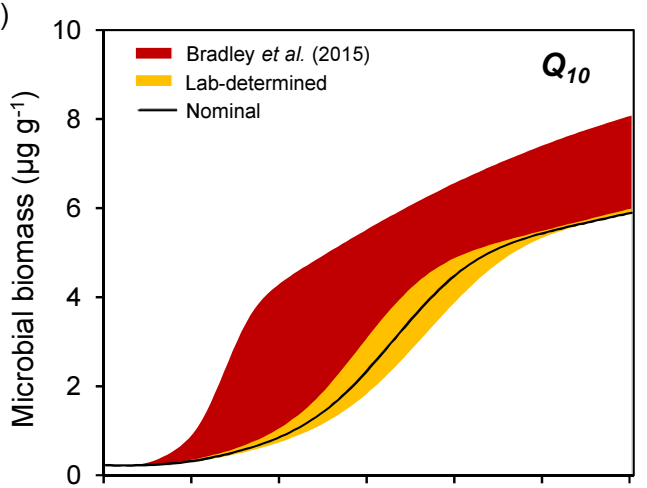

(c)

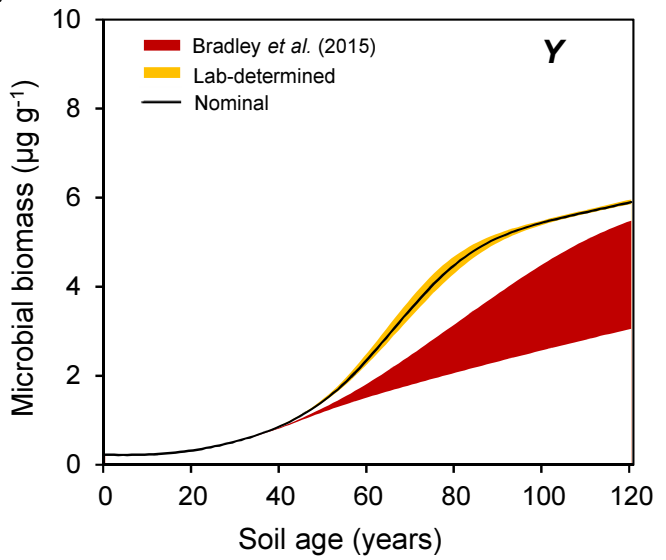

Figure 6. A comparison of predicted microbial biomass with laboratory-derived parameter values (yellow) and previously established parameter values (Bradley et al., 2015) (red) for variation in the following parameters: (a) maximum growth rate $\left(I_{\max }\right)$, (b) temperature response $\left(Q_{10}\right)$, and (c) $\operatorname{BGE}(Y)$.

ity in microbial activity via mathematical formulations (e.g. Monod kinetics; see Bradley et al., 2015) affixed to parameter values. A second assumption is the assignment of measured rates to parameters for all microbial functional groups. Rather than taxonomic based classification, SHIMMER distinguishes and classifies microbial communities based on functional traits. The mathematical formulations assigned to, for example, microbial growth are different between groups to represent distinct functional traits associated with that group. Whilst actual rates may be different between different organisms, for the level of model complexity and outputs required, a community measurement of those parameters is sufficient, particularly considering that the differences are accounted for in the mathematical formulation of SHIMMER (see Bradley et al., 2015). Third, maximum microbial growth rate at $T_{\text {ref }}\left(25^{\circ} \mathrm{C}\right.$; Bradley et al., 2015) as modelled in SHIMMER is modified by Monod terms that account for nutrient limitation (e.g. Monod terms), as well as a temperature response function $\left(Q_{10}\right)$ to estimate actual growth rate at ambient temperature. A major objective of this study was to improve model performance by constraining previously identified key model parameters (see sensitivity study results in Bradley at al., 2015) through specifically designed laboratory experiments. We showed this by comparing model simulation results applying measured, site-specific parameters with simulation results using a range of parameter values reported in the literature (Fig. 6).

\subsection{Microbial biomass dynamics and community structure}

Measured microbial biomass in the initial soils of Midtre Lovénbreen $\left(0.23 \mu \mathrm{g} \mathrm{Cg}^{-1}, 0\right.$ years) was very low compared to initial soils in other deglaciated forefields of equivalent ages in lower latitudes, for example in the Alps $\left(4 \mu \mathrm{g} \mathrm{Cg}^{-1}\right.$; Bernasconi et al., 2011; Tscherko et al., 2003) and Canada (6 $\mu \mathrm{g} \mathrm{C} \mathrm{g}^{-1}$; Insam and Haselwandter, 1989). However, our microbial biomass values are more similar to other recently deglaciated soils in Antarctica (Ecology Glacier $0.88 \mu \mathrm{g} \mathrm{C} \mathrm{g}^{-1}$; Zdanowski et al., 2013). Low biomass is possibly a result of the harsh, ultra-oligotrophic and nutrientlimiting environment of the High Arctic and Antarctica, where low temperature and longer winters limit the summer growth phase, especially compared to an Alpine system (Tscherko et al., 2003; Bernasconi et al., 2011).

The initial microbial community structure in our samples was predominantly autotrophic $(74.5 \%)$. In the years following exposure, we observed an increase in autotrophs and heterotrophs with soil age (Table 2), presumably due to the establishment and growth of stable soil microbial communities (Schulz et al., 2013; Bradley et al., 2014). Both the observations and modelling results suggested that there was no substantial increase in heterotrophic biomass during the initial and early-intermediate stages of soil development (years 0 to 40), which was then followed by a growth phase whereby biomass increased by roughly an order of magnitude. Overall, the model and the microscopy data were in good agreement, accounting for the limitations in both techniques, spatial heterogeneity, and the oscillations in biomass arising from seasonality (Fig. 7). SHIMMMER predicted that low initial microbial populations have the potential to considerably increase in population density during several decades of soil development. These data thus support the 
(a)

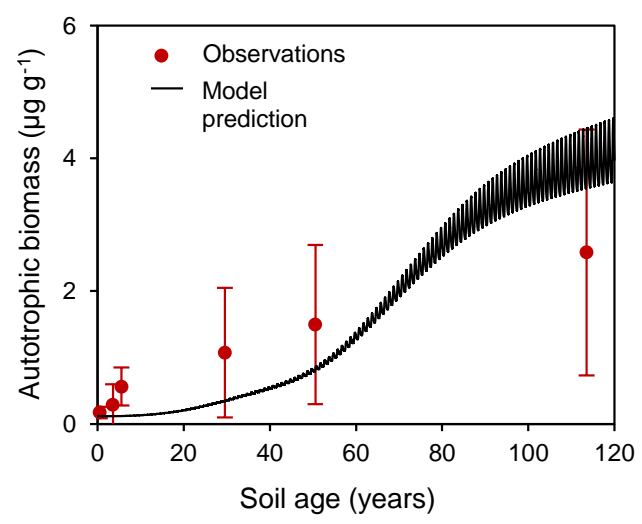

(b)

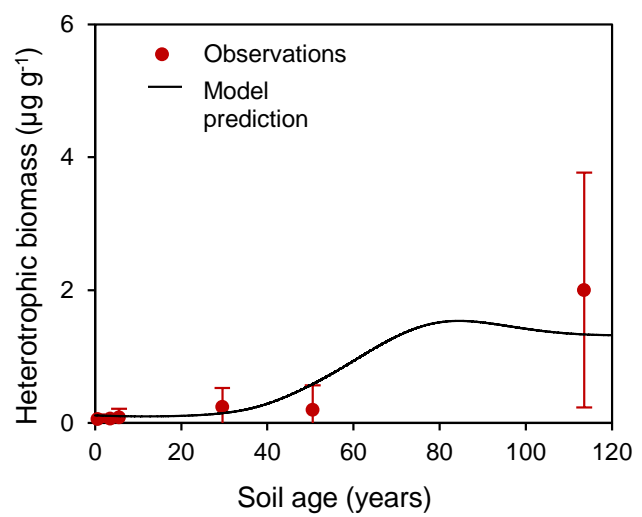

Figure 7. Model predictions of (a) autotrophic and (b) heterotrophic biomass (black line) compared to observational data (red) derived from microscopy.

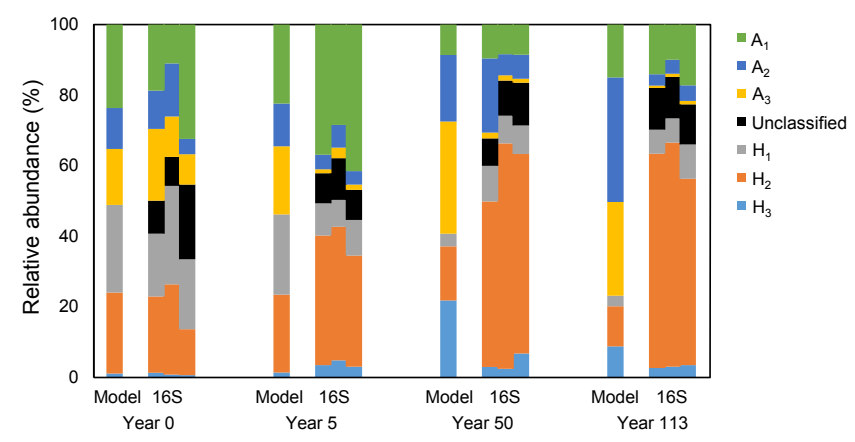

Figure 8. A comparison of microbial diversity from model output and genomic analyses at 0-, 5-, 50-, and 113-year-old soil.

hypothesis that the observed increase in microbial biomass with soil age is a consequence of in situ growth and activity. The pattern of microbial abundance observed in the Midtre Lovénbreen forefield broadly resembles that of other glacier forefields worldwide (see Bradley et al., 2014). For example, data from the Rootmoos Ferner (Austria; Insam and Haselwandter, 1989), Athabasca (Canada; Insam and Haselwandter, 1989), Damma (Switzerland; Bernasconi et al., 2011; Schulz et al., 2013), and Puca (Peru; Schmidt et al., 2008) glacier forefields find increased microbial biomass and activity over decades to centuries of soil development following exposure.

The genomic data indicated that glacial microbes (such as members of the family Comamonadaceae) are dominant in recently exposed soils, in agreement with model results (Fig. 8). The community structure in year 5 was heavily dominated by chemolithoautotrophs $\left(A_{1}\right.$; including taxa Thiobacillus, Rhodoplanes, Acidithiobacillus, Nitrospira, Sulfurimonas, and others), which reflected findings from previous studies whereby chemolithoautotrophic bacteria contribute to the oxidation of $\mathrm{FeS}_{2}$ in proglacial moraines in Midtre Lovénbreen (Borin et al., 2010; Mapelli et al., 2011). These processes are also commonly described in other subglacial habitats (Boyd et al., 2014; Hamilton et al., 2013). Based on 16S data, the glacial community declined in relative abundance with soil age. This finding was also reflected in the model in years 50 and 113. As the age of the soil progressed, there was typically greater abundance of microbes representing typical soil bacteria (groups $\mathrm{A}_{2}$ and $\mathrm{H}_{2}$ including taxa Geobacter, Micrococcus, Actinoplanes, Sphingomonas, Pedobacter, Devosia, Frankia, and Rhizobium) in the 16S data and the model, thus the relative abundance of glacial microbes decreased. Relative abundance of microbial communities across the chronosequence is plotted at the phylum and genus level in the Supplement (Figs. S4 and S5). The overall trends show the relative increase in the proportion of Acidobacteria with soil age. They contain typical soil bacteria and are thus often used as markers of soil formation and soil development. They are usually associated with plant covered older soils with lower $\mathrm{pH}$ as they specialize in degradation of plant recalcitrant organic compounds. The younger soils, on the other hand, contained a relatively higher proportion of sequences of Proteobacteria (particularly Betaproteobacteria), Bacterioidetes, and Cyanobacteria, i.e. groups often associated with supra- or subglacial habitats.

Microscopic analyses indicated low total biomass in recently exposed soils (up to $1.7 \mu \mathrm{g} \mathrm{Cg}^{-1}$ in soil exposed for 50 years) that was comprised predominantly of autotrophic bacteria. Model simulations agreed well with microscopyderived data. Overall, the $16 \mathrm{~S}$ data, when categorized into functional groups as defined by the model, agreed well with the microscopy and model output in the very early stages of soil development. However, in later stages of soil development (50 years and older), microscopy and modelling suggested a continuation of predominantly autotrophic soil microbial communities, whereas $16 \mathrm{~S}$ sequence data notably indicated a predominantly heterotrophic community. With ex- 
tremely low biomass, cell counts derived from microscopy, as well as representation of relative abundance by $16 \mathrm{~S}$ extraction and amplification, can be largely skewed by relatively small changes in the soil microbial community. Furthermore, the comparative difficulty to lyse autotrophic bacteria (such as some groups of cyanobacteria) from an environmental sample compared to heterotrophic bacteria, and thus successfully amplify the $16 \mathrm{~S}$ gene during the PCR process, may skew 16S sequence data in favour of heterotrophic sequence reads. Incomplete sequencing depth (shown by rarefaction curves, Fig. S6), the differential extractability of DNA from different organisms, and variation in rDNA copy number add potential for error in the presented $16 \mathrm{~S}$ data, and thus absolute numbers should be treated with caution. SHIMMER is an ambitious model in that it attempts to simulate, predict, and constrain multiple functional types of bacterial species or multiple microbial functional groups that are often extremely challenging to constrain (Servedio et al., 2014; Hellweger and Bucci, 2009; Jessup et al., 2004; Larsen et al., 2012), and as such the majority of microbial soil models often only resolve one or two living biomass pools that represent the bulk activity and function of the entire community (see, e.g., Manzoni et al., 2004; Manzoni and Porporato, 2007; Blagodatsky and Richter, 1998; Ingwersen et al., 2008; Wang et al., 2014). Our rationale for resolving six distinct functional groups was to quantitatively assess, using modelling, the relative importance and role of each functional group at different stages of soil development. Regardless of discrepancies in older soils (over 50 years since exposure), both the $16 \mathrm{~S}$ and microscopy data indicated that there was a mixed community of autotrophs and heterotrophs in soils of all ages, which was supported by modelling, since no functional groups were extirpated over simulations representing 120 years of soil development. Thus, SHIMMER is able to capture the diversity of the samples over 120 years of soil development, but the detailed community composition requires further investigation.

Nitrogen-fixing bacteria such as Nostoc, Rivularia, Pseudanabaena, and Rhodobacter were prevalent in recently exposed soils but declined in relative abundance with soil age. By fixing $\mathrm{N}_{2}$ instead of assimilating DIN, the model predicted that nitrogen fixers were able to grow rapidly in the early stages relative to other organisms (Fig. 4a, b). The model prediction supports findings by previous studies demonstrating the importance of nitrogen fixation in Alpine (Duc et al., 2009; Schmidt et al., 2008) and Antarctic (Strauss et al., 2012) glacier forefields and other High Arctic (Svalbard, Greenland) glacial ecosystems (Telling et al., 2011, 2012). However, there was poor agreement on the relative abundance of nitrogen fixers between the model and the $16 \mathrm{~S}$ data in the later stages of soil development (years 50 to 120), particularly between autotrophs and heterotrophs. The model over-predicted the relative abundance of nitrogen-fixing organisms (Fig. 8). The majority of the biomass of the autotrophic nitrogen fixers was composed of sequences belong- ing to the cyanobacterium from the genus Nostoc. Nostoc forms macroscopically visible colonies that grow on the surface of soils. Its distribution in Arctic soils is thus extremely patchy, and therefore part of the discrepancy between the 16S data and the model regarding the relative distribution of the $A_{3}$ group in the older soils could be due to under-sampling of the Nostoc colonies as a consequence of a random sampling approach. Furthermore, allochthonous inputs of nitrogen to the Arctic (e.g. aerial deposition; Geng et al., 2014) strongly affect the productivity of microbial ecosystems and the requirement of nitrogen fixation for microbes (Bjorkman et al., 2013; Kuhnel et al., 2011, 2013; Hodson et al., 2010; Telling et al., 2012; Galloway et al., 2008). Thus, uncertainty in the allochthonous availability of nitrogen strongly affects nitrogen fixation rates. In attempting to replicate a qualitative understanding of the nitrogen cycle in a quantitative mathematical modelling framework, the predicted importance of nitrogen-fixing organisms may be overestimated. The poor agreement in the relative abundance of nitrogen fixers between the model and the 16S data indicates an incomplete understanding of allochthonous versus autochthonous nutrient availability. Allochthonous nutrient availability is a known source of uncertainty (Bradley et al., 2014; Schulz et al., 2013; Schmidt et al., 2008), and addressing this concern is the subject of future work.

$16 \mathrm{~S}$ data are an exciting resource of information that is rarely (or never) used to test numerical process-based biogeochemical models. However, the environment (difficulty to extract DNA), the presentation (percentages of low concentration and thus easy to shift relative abundance), the potentially high proportion of dead or dormant cells (which may be present in sequence data but are not necessarily metabolically active), the differential extractability of DNA from different organisms and variation in rDNA copy number, and uncertainties in model formulation make comparisons challenging. In making this first attempt at comparison of model output to $16 \mathrm{~S}$ data, we hope to spark discussion and further development of approaches that have similar objectives in order to improve future model performance.

\subsection{Net ecosystem metabolism and carbon budget}

Allochthonous carbon inputs were the most significant contributor to recently exposed soils (e.g. year 5), since the total change in substrate closely followed this flux (Fig. 5). In older soils (year 113), biotic fluxes were substantially higher, and microbial necromass contributed equally as a source of organic substrate compared to allochthonous deposition. In the older soils, heterotrophic growth and respiration caused substantial consumption and thus depletion of available carbon stocks. This evidence thus supports the hypothesis that carbon fluxes in very recently exposed soils are low and are dominated by abiotic processes (i.e. allochthonous deposition), whereas biotic processes (such as microbial growth, respiration, and cell death) play a greater role in developed 
soils with increased microbial abundance and activity. These findings for Midtre Lovénbreen in the High Arctic are similar to what has been observed based on empirical evidence from Alpine settings (at the Damma Glacier, Switzerland; Smittenberg et al., 2012; Guelland et al., 2013b).

The seasonality of carbon fluxes predicted by the model (Fig. 5b and c) related to the high measured $Q_{10}$ values. High seasonal variation in biotic fluxes and rates is typical of cryospheric soil ecosystems (Schostag et al., 2015), including Alpine glacier forefield soils (Lazzaro et al., 2012, 2015). However, microbial activity has been shown to persist during winter under insulating layers of snow and in sub-zero temperatures (Zhang et al., 2014). Modelling also predicted sustained organic substrate degradation, microbial turnover, and net heterotrophy during the winter (Fig. $5 \mathrm{~b}$ and c), as documented in other glacier forefield studies from an Alpine setting (Guelland et al., 2013b).

The low measured BGE has three important consequences. Firstly, low BGE suggests that a large pool of substrate is required to support heterotrophic growth. Low-efficiency heterotrophic growth led to the rapid depletion of substrate; therefore, high allochthonous inputs were required to maintain a sizeable pool. In older soils (years 80 to 120), increased inputs from microbial necromass (blue line, Fig. 5d) sustained substrate supply to heterotrophs. The sources of allochthonous carbon substrate to the glacier forefield include meltwater inputs derived from the supraglacial and subglacial ecosystems (Stibal et al., 2008; Hodson et al., 2005; Mindl et al., 2007), snow algae (which are known to be prolific primary colonizers and producers in High Arctic snowpacks; Lutz et al., 2014, 2015), atmospheric deposition (Kuhnel et al., 2013), and ornithogenic deposition (e.g. faecal matter of birds and animals; Jakubas et al., 2008; Ziolek and Melke, 2014; Luoto et al., 2015; Michelutti et al., 2009, 2011; Moe et al., 2009). Microbial dynamics are moderately sensitive to external allochthonous inputs of substrate (Bradley et al., 2015), and addressing the uncertainty associated with this flux is an important question to address in future research.

Secondly, low BGE causes a net efflux of $\mathrm{CO}_{2}$ over the first 120 years of soil development despite high autotrophic production (Fig. 4e and f). Recent literature has explored the carbon dynamics of glacier forefield ecosystems, finding highly variable soil respiration rates (Bekku et al., 2004; Schulz et al., 2013; Guelland et al., 2013a). Future studies should focus on quantifying carbon and nutrient transformations and the potential for forefield systems to impact global biogeochemical cycles in response to future climate change (Smittenberg et al., 2012) and in the context of large-scale ice retreat.

Thirdly, high rates of substrate degradation encouraged by low BGE were responsible for rapid nutrient release. Modelling suggested that microbial growth was strongly inhibited by low nutrient availability in initial soils $\left(4 \mu \mathrm{g} \mathrm{N} \mathrm{g}^{-1}, 2\right.$ to $10 \mu \mathrm{P} \mathrm{g}^{-1}$; Fig. 4d). This is consistent with findings from the Hailuogou Glacier (Gongga Shan, China) and Damma Glacier (Switzerland; Prietzel et al., 2013). Low BGE is predicted by the model to have a very important role in encouraging the release of nutrients from organic material more rapidly, thereby increasing total bacterial production in the intermediate stages of soil development. Increased nutrient availability with increased heterotrophic biomass is consistent with recent observations from glacier forefields (Bekku et al., 2004; Schulz et al., 2013; Schmidt et al., 2008).

\section{Conclusions}

We used laboratory-based mesocosm experiments to measure three key model parameters: maximum microbial growth rate $\left(I_{\max }\right.$; by incorporation of ${ }^{3} \mathrm{H}$-leucine), BGE $(Y$; by measuring respiration rates), and the temperature response ( $Q_{10}$; by measuring rates at different ambient temperatures). Laboratory-derived parameters were comparable with previous estimations. We refined model predictions constraining site-specific parameters by lab experiments, thus decreasing parameter uncertainty and narrowing the range of model output over nominal environmental conditions. A comparison of model simulations using laboratory-derived parameter values and previously defined parameter values showed that the coupling of high $Q_{10}$ values and low BGE were important factors in controlling biomass accumulation due to promoting survival of biomass during periods of low temperature and the enhanced recycling of nutrients through organic matter degradation, respectively. Our results demonstrated that in situ microbial growth lead to the overall accumulation of microbial biomass in the Midtre Lovénbreen forefield during the first century of soil development following exposure. Furthermore, carbon fluxes increased in older soils due to elevated biotic (microbial) activity. Microbial dynamics at the initial stages of soil development in glacial forefields do not contribute to significant accumulation of organic carbon due to the very low growth efficiency of the microbial community, resulting in a net efflux of $\mathrm{CO}_{2}$ from those habitats. However, the low bacterial growth efficiency in glacial forefields is also responsible for high rates of nutrient remineralization, which most probably has an important role on the establishment of plants at older ages. The relative importance of allochthonous versus autochthonous substrate and nutrients is the focus of future research.

This exercise shows how an integrated model-data approach can improve understanding and predictions of microbial dynamics in forefield soils and disentangle complex process interactions to ascertain the relative importance of each process individually. This would, for annual budgets, be extremely challenging with a purely empirical approach. Nevertheless, more clarity and data are needed in tracing the dynamics and interactions of these carbon pools to improve confidence and validate model simulations. Proglacial zones are expanding due to accelerated ice retreat. Thus, 
glacier forefields are becoming an increasingly important novel habitat for microorganisms in glaciated regions experiencing rapid changes in climate. This combined approach explored detailed microbial and biogeochemical dynamics of soil development, with the view of obtaining a more holistic picture of soil development in a warmer and increasingly icefree future world.

\section{Data availability}

Sequence data are available from the NCBI under project ID PRJNA341831, and individual accession numbers are provided in the supplement to this article.

\section{The Supplement related to this article is available online at doi:10.5194/bg-13-5677-2016-supplement.}

Acknowledgements. We thank Siegrid Debatin, Marion Maturilli, and Julia Boike (AWI) for support in acquiring meteorological and radiation data; Simon Cobb, James Williams, Jane Coghill, and Christy Waterfall (University of Bristol) for laboratory assistance; and Nicholas Cox and James Wake for assistance in the field and use of the UK Arctic Research Station base in Ny-Ålesund. We also thank Arwyn Edwards (Aberystwyth University) and the two anonymous referees, who provided valuable comments on the manuscript. This research was supported by NERC grant no. NE/J02399X/1 to Alexandre M. Anesio. Sandra Arndt acknowledges support from NERC grant no. NE/IO21322/1.

Edited by: M. Weintraub

Reviewed by: A. Edwards and two anonymous referees

\section{References}

ACIA: Arctic Climate Impacts Assessment, Cambridge University Press, Cambridge, 1042 pp., 2005.

Alves, R. J. E., Wanek, W., Zappe, A., Richter, A., Svenning, M. M., Schleper, C., and Urich, T.: Nitrification rates in Arctic soils are associated with functionally distinct populations of ammonia-oxidizing archaea, Isme J., 7, 1620-1631, doi:10.1038/ismej.2013.35, 2013.

Anderson, S. P., Drever, J. I., Frost, C. D., and Holden, P.: Chemical weathering in the foreland of a retreating glacier, Geochim. Cosmochim. Ac., 64, 1173-1189, doi:10.1016/S00167037(99)00358-0, 2000.

Anesio, A. M., Sattler, B., Foreman, C., Telling, J., Hodson, A., Tranter, M., and Psenner, R.: Carbon fluxes through bacterial communities on glacier surfaces, Ann. Glaciol., 51, 32-40, 2010.

Bekku, Y. S., Nakatsubo, T., Kume, A., and Koizumi, H.: Soil microbial biomass, respiration rate, and temperature dependence on a successional glacier foreland in Ny-Alesund, Svalbard, Arct. Antarct. Alp. Res., 36, 395-399, 2004.
Bernasconi, S. M., Bauder, A., Bourdon, B., Brunner, I., Bunemann, E., Christl, I., Derungs, N., Edwards, P., Farinotti, D., Frey, B., Frossard, E., Furrer, G., Gierga, M., Goransson, H., Gulland, K., Hagedorn, F., Hajdas, I., Hindshaw, R., Ivy-Ochs, S., Jansa, J., Jonas, T., Kiczka, M., Kretzschmar, R., Lemarchand, E., Luster, J., Magnusson, J., Mitchell, E. A. D., Venterink, H. O., Plotze, M., Reynolds, B., Smittenberg, R. H., Stahli, M., Tamburini, F., Tipper, E. T., Wacker, L., Welc, M., Wiederhold, J. G., Zeyer, J., Zimmermann, S., and Zumsteg, A.: Chemical and Biological Gradients along the Damma Glacier Soil Chronosequence, Switzerland, Vadose Zone J., 10, 867-883, doi:10.2136/Vzj2010.0129, 2011.

Berner, R. A., Lasaga, A. C., and Garrels, R. M.: The CarbonateSilicate Geochemical Cycle and Its Effect on Atmospheric Carbon-Dioxide over the Past 100 Million Years, Am. J. Sci., 283, 641-683, 1983.

Bjorkman, M. P., Kuhnel, R., Partridge, D. G., Roberts, T. J., Aas, W., Mazzola, M., Viola, A., Hodson, A., Strom, J., and Isaksson, E.: Nitrate dry deposition in Svalbard, Tellus B, 65, 19071, doi:10.3402/Tellusb.V65i0.19071, 2013.

Blagodatsky, S. A. and Richter, O.: Microbial growth in soil and nitrogen turnover: A theoretical model considering the activity state of microorganisms, Soil Biol. Biochem., 30, 1743-1755, doi:10.1016/S0038-0717(98)00028-5, 1998.

Blagodatsky, S. A., Yevdokimov, I. V., Larionova, A. A., and Richter, J.: Microbial growth in soil and nitrogen turnover: Model calibration with laboratory data, Soil Biol. Biochem., 30, 1757-1764, doi:10.1016/S0038-0717(98)00029-7, 1998.

Borin, S., Ventura, S., Tambone, F., Mapelli, F., Schubotz, F., Brusetti, L., Scaglia, B., D’Acqui, L. P., Solheim, B., Turicchia, S., Marasco, R., Hinrichs, K. U., Baldi, F., Adani, F., and Daffonchio, D.: Rock weathering creates oases of life in a High Arctic desert, Environ. Microbiol., 12, 293-303, doi:10.1111/j.14622920.2009.02059.x, 2010.

Boyd, E. S., Hamilton, T. L., Havig, J. R., Skidmore, M. L., and Shock, E. L.: Chemolithotrophic Primary Production in a Subglacial Ecosystem, Appl. Environ. Microb., 80, 6146-6153, doi:10.1128/Aem.01956-14, 2014.

Bradley, J. A., Singarayer, J. S., and Anesio, A. M.: Microbial community dynamics in the forefield of glaciers, Proceedings, Biological sciences/The Royal Society, 281, 2793-2802, doi:10.1098/rspb.2014.0882, 2014.

Bradley, J. A., Anesio, A. M., Singarayer, J. S., Heath, M. R., and Arndt, S.: SHIMMER (1.0): a novel mathematical model for microbial and biogeochemical dynamics in glacier forefield ecosystems, Geosci. Model Dev., 8, 3441-3470, doi:10.5194/gmd-83441-2015, 2015.

Bradley, J. A., Anesio, A., and Arndt, S.: Bridging the divide: a model-data approach to Polar \& Alpine Microbiology, Fems Microbiol. Ecol., 92, fiw015, doi:10.1093/femsec/fiw015, 2016.

Bratbak, G. and Dundas, I.: Bacterial Dry-Matter Content and Biomass Estimations, Appl. Environ. Microb., 48, 755-757, 1984.

Brown, S. P. and Jumpponen, A.: Contrasting primary successional trajectories of fungi and bacteria in retreating glacier soils, Mol. Ecol., 23, 481-497, doi:10.1111/Mec.12487, 2014.

Caporaso, J. G., Kuczynski, J., Stombaugh, J., Bittinger, K., Bushman, F. D., Costello, E. K., Fierer, N., Pena, A. G., Goodrich, J. K., Gordon, J. I., Huttley, G. A., Kelley, S. T., Knights, 
D., Koenig, J. E., Ley, R. E., Lozupone, C. A., McDonald, D., Muegge, B. D., Pirrung, M., Reeder, J., Sevinsky, J. R., Tumbaugh, P. J., Walters, W. A., Widmann, J., Yatsunenko, T., Zaneveld, J., and Knight, R.: QIIME allows analysis of highthroughput community sequencing data, Nat. Methods, 7, 335336, doi:10.1038/nmeth.f.303, 2010.

Caporaso, J. G., Lauber, C. L., Walters, W. A., Berg-Lyons, D., Huntley, J., Fierer, N., Owens, S. M., Betley, J., Fraser, L., Bauer, M., Gormley, N., Gilbert, J. A., Smith, G., and Knight, R.: Ultra-high-throughput microbial community analysis on the Illumina HiSeq and MiSeq platforms, ISME J., 6, 1621-1624, doi:10.1038/ismej.2012.8, 2012.

Cary, S. C., McDonald, I. R., Barrett, J. E., and Cowan, D. A.: On the rocks: the microbiology of Antarctic Dry Valley soils, Nat. Rev. Microbiol., 8, 129-138, doi:10.1038/nrmicro2281, 2010.

Darrah, P. R.: Models of the Rhizosphere; 1. Microbial-Population Dynamics around a Root Releasing Soluble and Insoluble Carbon, Plant Soil, 133, 187-199, doi:10.1007/Bf00009191, 1991.

Dessert, C., Dupre, B., Gaillardet, J., Francois, L. M., and Allegre, C. J.: Basalt weathering laws and the impact of basalt weathering on the global carbon cycle, Chem. Geol., 202, 257-273, doi:10.1016/j.chemgeo.2002.10.001, 2003.

Duc, L., Noll, M., Meier, B. E., Burgmann, H., and Zeyer, J.: High Diversity of Diazotrophs in the Forefield of a Receding Alpine Glacier, Microb. Ecol., 57, 179-190, doi:10.1007/s00248-0089408-5, 2009.

Dyurgerov, M. B. and Meier, M. F.: Twentieth century climate change: Evidence from small glaciers, P. Natl. Acad. Sci. USA, 97, 1406-1411, doi:10.1073/pnas.97.4.1406, 2000.

Edgar, R. C., Haas, B. J., Clemente, J. C., Quince, C., and Knight, R.: UCHIME improves sensitivity and speed of chimera detection, Bioinformatics, 27, 2194-2200, doi:10.1093/bioinformatics/btr381, 2011.

Ensign, K. L., Webb, E. A., and Longstaffe, F. J.: Microenvironmental and seasonal variations in soil water content of the unsaturated zone of a sand dune system at Pinery Provincial Park, Ontario, Canada, Geoderma, 136, 788-802, doi:10.1016/j.geoderma.2006.06.009, 2006.

Esperschütz, J., Pérez-de-Mora, A., Schreiner, K., Welzl, G., Buegger, F., Zeyer, J., Hagedorn, F., Munch, J. C., and Schloter, M.: Microbial food web dynamics along a soil chronosequence of a glacier forefield, Biogeosciences, 8, 3283-3294, doi:10.5194/bg8-3283-2011, 2011.

Fleming, K. M., Dowdeswell, J. A., and Oerlemans, J.: Modelling the mass balance of northwest Spitsbergen glaciers and responses to climate change, Ann. Glaciol., 24, 203-210, 1997.

Foereid, B. and Yearsley, J. M.: Modelling the impact of microbial grazers on soluble rhizodeposit turnover, Plant Soil, 267, 329342, doi:10.1007/s11104-005-0139-9, 2004.

Frey, B., Rieder, S. R., Brunner, I., Plotze, M., Koetzsch, S., Lapanje, A., Brandl, H., and Furrer, G.: Weathering-Associated Bacteria from the Damma Glacier Forefield: Physiological Capabilities and Impact on Granite Dissolution, Appl. Environ. Microb., 76, 4788-4796, doi:10.1128/Aem.00657-10, 2010.

Frey, B., Buhler, L., Schmutz, S., Zumsteg, A., and Furrer, G.: Molecular characterization of phototrophic microorganisms in the forefield of a receding glacier in the Swiss Alps, Environ. Res. Lett., 8, 015033, doi:10.1088/1748-9326/8/1/015033, 2013.
Galloway, J. N., Townsend, A. R., Erisman, J. W., Bekunda, M., Cai, Z. C., Freney, J. R., Martinelli, L. A., Seitzinger, S. P., and Sutton, M. A.: Transformation of the nitrogen cycle: Recent trends, questions, and potential solutions, Science, 320, 889-892, doi:10.1126/science.1136674, 2008.

Geng, L., Alexander, B., Cole-Dai, J., Steig, E. J., Savarino, J., Sofen, E. D., and Schauer, A. J.: Nitrogen isotopes in ice core nitrate linked to anthropogenic atmospheric acidity change, P. Natl. Acad. Sci. USA, 111, 5808-5812, doi:10.1073/pnas.1319441111, 2014.

Goransson, H., Venterink, H. O., and Baath, E.: Soil bacterial growth and nutrient limitation along a chronosequence from a glacier forefield, Soil Biol. Biochem., 43, 1333-1340, doi:10.1016/j.soilbio.2011.03.006, 2011.

Guelland, K., Esperschutz, J., Bornhauser, D., Bernasconi, S. M., Kretzschmar, R., and Hagedorn, F.: Mineralisation and leaching of $\mathrm{C}$ from $\mathrm{C}$-13 labelled plant litter along an initial soil chronosequence of a glacier forefield, Soil Biol. Biochem., 57, 237-247, doi:10.1016/j.soilbio.2012.07.002, 2013a.

Guelland, K., Hagedorn, F., Smittenberg, R. H., Goransson, H., Bernasconi, S. M., Hajdas, I., and Kretzschmar, R.: Evolution of carbon fluxes during initial soil formation along the forefield of Damma glacier, Switzerland, Biogeochemistry, 113, 545-561, doi:10.1007/s10533-012-9785-1, 2013b.

Hamilton, T. L., Peters, J. W., Skidmore, M. L., and Boyd, E. S.: Molecular evidence for an active endogenous microbiome beneath glacial ice, Isme J., 7, 1402-1412, doi:10.1038/ismej.2013.31, 2013.

Hellweger, F. L. and Bucci, V.: A bunch of tiny individualsIndividual-based modeling for microbes, Ecol. Model., 220, 822, doi:10.1016/j.ecolmodel.2008.09.004, 2009.

Hodkinson, I. D., Coulson, S. J., and Webb, N. R.: Community assembly along proglacial chronosequences in the high Arctic: vegetation and soil development in north-west Svalbard, J. Ecol., 91, 651-663, doi:10.1046/j.1365-2745.2003.00786.x, 2003.

Hodson, A., Anesio, A. M., Ng, F., Watson, R., Quirk, J., IrvineFynn, T., Dye, A., Clark, C., McCloy, P., Kohler, J., and Sattler, B.: A glacier respires: Quantifying the distribution and respiration $\mathrm{CO}_{2}$ flux of cryoconite across an entire Arctic supraglacial ecosystem, J. Geophys. Res.-Biogeo., 112, G04s36, doi:10.1029/2007jg000452, 2007.

Hodson, A., Roberts, T. J., Engvall, A. C., Holmen, K., and Mumford, P.: Glacier ecosystem response to episodic nitrogen enrichment in Svalbard, European High Arctic, Biogeochemistry, 98, 171-184, doi:10.1007/s10533-009-9384-y, 2010.

Hodson, A. J., Mumford, P. N., Kohler, J., and Wynn, P. M.: The High Arctic glacial ecosystem: new insights from nutrient budgets, Biogeochemistry, 72, 233-256, doi:10.1007/s10533-0040362-0, 2005.

Ingwersen, J., Poll, C., Streck, T., and Kandeler, E.: Micro-scale modelling of carbon turnover driven by microbial succession at a biogeochemical interface, Soil Biol. Biochem., 40, 864-878, doi:10.1016/j.soilbio.2007.10.018, 2008.

Insam, H. and Haselwandter, K.: Metabolic Quotient of the Soil Microflora in Relation to Plant Succession, Oecologia, 79, 174 178, doi:10.1007/Bf00388474, 1989.

Jakubas, D., Zmudczynska, K., Wojczulanis-Jakubas, K., and Stempniewicz, L.: Faeces deposition and numbers of vertebrate herbivores in the vicinity of planktivorous and piscivorous 
seabird colonies in Hornsund, Spitsbergen, Polar Res., 29, 4558, 2008.

Jessup, C. M., Kassen, R., Forde, S. E., Kerr, B., Buckling, A., Rainey, P. B., and Bohannan, B. J. M.: Big questions, small worlds: microbial model systems in ecology, Trends Ecol. Evol., 19, 189-197, doi:10.1016/j.tree.2004.01.008, 2004.

Johannessen, O. M., Bengtsson, L., Miles, M. W., Kuzmina, S. I., Semenov, V. A., Alekseev, G. V., Nagurnyi, A. P., Zakharov, V. F., Bobylev, L. P., Pettersson, L. H., Hasselmann, K., and Cattle, A. P.: Arctic climate change: observed and modelled temperature and sea-ice variability, Tellus A, 56, 328-341, doi:10.1111/j.1600-0870.2004.00060.x, 2004.

Kastovska, K., Elster, J., Stibal, M., and Santruckova, H.: Microbial assemblages in soil microbial succession after glacial retreat in Svalbard (high Arctic), Microb. Ecol., 50, 396-407, doi:10.1007/s00248-005-0246-4, 2005.

King, A. J., Meyer, A. F., and Schmidt, S. K.: High levels of microbial biomass and activity in unvegetated tropical and temperate alpine soils, Soil Biol. Biochem., 40, 2605-2610, doi:10.1016/j.soilbio.2008.06.026, 2008.

Kirchman, D.: Measuring Bacterial Biomass Production and Growth Rates from Leucine Incorporation in Natural Aquatic Environments in: Marine Microbiology, edited by: Paul, J. H., Academic Press, London, UK, 2001.

Knapp, E. B., Elliott, L. F., and Campbell, G. S.: Carbon, Nitrogen and Microbial Biomass Interrelationships during the Decomposition of Wheat Straw - a Mechanistic Simulation-Model, Soil Biol. Biochem., 15, 455-461, doi:10.1016/0038-0717(83)90011$1,1983$.

Kuhnel, R., Roberts, T. J., Bjorkman, M. P., Isaksson, E., Aas, W., Holmen, K., and Strom, J.: 20-Year Climatology of $\mathrm{NO}_{3}^{-}$and $\mathrm{NH}_{4}^{+}$Wet Deposition at Ny-Alesund, Svalbard, Adv. Meteorol., 2011, 406508, doi:10.1155/2011/406508, 2011.

Kuhnel, R., Bjorkman, M. P., Vega, C. P., Hodson, A., Isaksson, E., and Strom, J.: Reactive nitrogen and sulphate wet deposition at Zeppelin Station, Ny-Alesund, Svalbard, Polar Res., 32, 19136, doi:10.3402/Polar.V32i0.19136, 2013.

Larsen, P., Hamada, Y., and Gilbert, J.: Modeling microbial communities: Current, developing, and future technologies for predicting microbial community interaction, J. Biotechnol., 160, 17-24, doi:10.1016/j.jbiotec.2012.03.009, 2012.

Lazzaro, A., Brankatschk, R., and Zeyer, J.: Seasonal dynamics of nutrients and bacterial communities in unvegetated alpine glacier forefields, Appl. Soil Ecol., 53, 10-22, doi:10.1016/j.apsoil.2011.10.013, 2012.

Lazzaro, A., Hilfiker, D., and Zeyer, J.: Structures of Microbial Communities in Alpine Soils: Seasonal and Elevational Effects, Front. Microbiol., 6, 1330, doi:10.3389/fmicb.2015.01330, 2015.

Lee, S.: A theory for polar amplification from a general circulation perspective, Asia-Pac., J. Atmos. Sci., 50, 31-43, doi:10.1007/s13143-014-0024-7, 2014.

Luoto, T. P., Oksman, M., and Ojala, A. E. K.: Climate change and bird impact as drivers of High Arctic pond deterioration, Polar Biol., 38, 357-368, doi:10.1007/s00300-014-1592-9, 2015.

Lutz, S., Anesio, A. M., Villar, S. E. J., and Benning, L. G.: Variations of algal communities cause darkening of a Greenland glacier, Fems Microbiol. Ecol., 89, 402-414, doi:10.1111/15746941.12351, 2014.
Lutz, S., Anesio, A. M., Edwards, A., and Benning, L. G.: Microbial diversity on Icelandic glaciers and ice caps, Front. Microbiol., 6, 307, doi:10.3389/fmicb.2015.00307, 2015.

Manzoni, S., Porporato, A., D’Odorico, P., Laio, F., and RodriguezIturbe, I.: Soil nutrient cycles as a nonlinear dynamical system, Nonlin. Processes Geophys., 11, 589-598, doi:10.5194/npg-11589-2004, 2004.

Manzoni, S. and Porporato, A.: A theoretical analysis of nonlinearities and feedbacks in soil carbon and nitrogen cycles, Soil Biol. Biochem., 39, 1542-1556, doi:10.1016/j.soilbio.2007.01.006, 2007.

Mapelli, F., Marasco, R., Rizzi, A., Baldi, F., Ventura, S., Daffonchio, D., and Borin, S.: Bacterial Communities Involved in Soil Formation and Plant Establishment Triggered by Pyrite Bioweathering on Arctic Moraines, Microb. Ecol., 61, 438-447, doi:10.1007/s00248-010-9758-7, 2011.

McDonald, D., Price, M. N., Goodrich, J., Nawrocki, E. P., DeSantis, T. Z., Probst, A., Andersen, G. L., Knight, R., and Hugenholtz, P.: An improved Greengenes taxonomy with explicit ranks for ecological and evolutionary analyses of bacteria and archaea, Isme J., 6, 610-618, doi:10.1038/ismej.2011.139, 2012.

Michelutti, N., Keatley, B. E., Brimble, S., Blais, J. M., Liu, H. J., Douglas, M. S. V., Mallory, M. L., Macdonald, R. W., and Smol, J. P.: Seabird-driven shifts in Arctic pond ecosystems, P. Roy. Soc. B-Biol. Sci., 276, 591-596, doi:10.1098/rspb.2008.1103, 2009.

Michelutti, N., Mallory, M. L., Blais, J. M., Douglas, M. S. V., and Smol, J. P.: Chironomid assemblages from seabird-affected High Arctic ponds, Polar Biol., 34, 799-812, doi:10.1007/s00300-0100934-5, 2011.

Mindl, B., Anesio, A. M., Meirer, K., Hodson, A. J., LaybournParry, J., Sommaruga, R., and Sattler, B.: Factors influencing bacterial dynamics along a transect from supraglacial runoff to proglacial lakes of a high Arctic glacieri (vol 7, pg 307, 2007), Fems Microbiol. Ecol., 59, 762-762, doi:10.1111/j.15746941.2007.00295.x, 2007.

Moe, B., Stempniewicz, L., Jakubas, D., Angelier, F., Chastel, O., Dinessen, F., Gabrielsen, G. W., Hanssen, F., Karnovsky, N. J., Ronning, B., Welcker, J., Wojczulanis-Jakubas, K., and Bech, C.: Climate change and phenological responses of two seabird species breeding in the high-Arctic, Mar. Ecol.-Prog. Ser., 393, 235-246, doi:10.3354/meps08222, 2009.

Moreau, M., Mercier, D., Laffly, D., and Roussel, E.: Impacts of recent paraglacial dynamics on plant colonization: A case study on Midtre Lovenbreen foreland, Spitsbergen $\left(79^{\circ} \mathrm{N}\right)$, Geomorphology, 95, 48-60, doi:10.1016/j.geomorph.2006.07.031, 2008.

Moritz, R. E., Bitz, C. M., and Steig, E. J.: Dynamics of recent climate change in the Arctic, Science, 297, 1497-1502, doi:10.1126/science.1076522, 2002.

Paul, F., Frey, H., and Le Bris, R.: A new glacier inventory for the European Alps from Landsat TM scenes of 2003: challenges and results, Ann. Glaciol., 52, 144-152, 2011.

Prietzel, J., Dumig, A., Wu, Y. H., Zhou, J., and Klysubun, W.: Synchrotron-based P K-edge XANES spectroscopy reveals rapid changes of phosphorus speciation in the topsoil of two glacier foreland chronosequences, Geochim. Cosmochim. Ac., 108, 154-171, doi:10.1016/j.gca.2013.01.029, 2013.

Schipper, L. A., Hobbs, J. K., Rutledge, S., and Arcus, V. L.: Thermodynamic theory explains the temperature optima of soil mi- 
crobial processes and high $Q(10)$ values at low temperatures, Glob. Change Biol., 20, 3578-3586, doi:10.1111/Gcb.12596, 2014.

Schloss, P. D., Westcott, S. L., Ryabin, T., Hall, J. R., Hartmann, M., Hollister, E. B., Lesniewski, R. A., Oakley, B. B., Parks, D. H., Robinson, C. J., Sahl, J. W., Stres, B., Thallinger, G. G., Van Horn, D. J., and Weber, C. F.: Introducing mothur: Open-Source, Platform-Independent, Community-Supported Software for Describing and Comparing Microbial Communities, Appl. Environ. Microb., 75, 7537-7541, doi:10.1128/Aem.01541-09, 2009.

Schmidt, S. K., Reed, S. C., Nemergut, D. R., Grandy, A. S., Cleveland, C. C., Weintraub, M. N., Hill, A. W., Costello, E. K., Meyer, A. F., Neff, J. C., and Martin, A. M.: The earliest stages of ecosystem succession in high-elevation (5000 metres above sea level), recently deglaciated soils, P. Roy. Soc. B-Biol. Sci., 275, 2793-2802, doi:10.1098/rspb.2008.0808, 2008.

Schostag, M., Stibal, M., Jacobsen, C. S., Baelum, J., Tas, N., Elberling, B., Jansson, J. K., Semenchuk, P., and Prieme, A.: Distinct summer and winter bacterial communities in the active layer of Svalbard permafrost revealed by DNA- and RNA-based analyses, Front. Microbiol., 6, 399, doi:10.3389/fmicb.2015.00399, 2015.

Schulz, S., Brankatschk, R., Dümig, A., Kögel-Knabner, I., Schloter, M., and Zeyer, J.: The role of microorganisms at different stages of ecosystem development for soil formation, Biogeosciences, 10, 3983-3996, doi:10.5194/bg-10-3983-2013, 2013.

Schutte, U. M. E., Abdo, Z., Bent, S. J., Williams, C. J., Schneider, G. M., Solheim, B., and Forney, L. J.: Bacterial succession in a glacier foreland of the High Arctic, Isme J., 3, 1258-1268, doi:10.1038/ismej.2009.71, 2009.

Scott, E. M., Rattray, E. A. S., Prosser, J. I., Killham, K., Glover, L. A., Lynch, J. M., and Bazin, M. J.: A Mathematical-Model for Dispersal of Bacterial Inoculants Colonizing the Wheat Rhizosphere, Soil Biol. Biochem., 27, 1307-1318, doi:10.1016/00380717(95)00050-O, 1995.

Serreze, M. C., Walsh, J. E., Chapin, F. S., Osterkamp, T., Dyurgerov, M., Romanovsky, V., Oechel, W. C., Morison, J., Zhang, T., and Barry, R. G.: Observational evidence of recent change in the northern high-latitude environment, Climatic Change, 46, 159-207, doi:10.1023/A:1005504031923, 2000.

Servedio, M. R., Brandvain, Y., Dhole, S., Fitzpatrick, C. L., Goldberg, E. E., Stern, C. A., Van Cleve, J., and Yeh, D. J.: Not just a theory-the utility of mathematical models in evolutionary biology, Plos Biol., 12, e1002017, doi:10.1371/journal.pbio.1002017, 2014.

Simon, M. and Azam, F.: Protein-Content and Protein-Synthesis Rates of Planktonic Marine-Bacteria, Mar. Ecol.-Prog. Ser., 51, 201-213, doi:10.3354/meps051201, 1989.

Smittenberg, R. H., Gierga, M., Goransson, H., Christl, I., Farinotti, D., and Bernasconi, S. M.: Climate-sensitive ecosystem carbon dynamics along the soil chronosequence of the Damma glacier forefield, Switzerland, Glob. Change Biol., 18, 19411955, doi:10.1111/j.1365-2486.2012.02654.x, 2012.

Soetaert, K. and Herman, P.: A Practical Guide to Ecological Modelling: Using R as a Simulation Platform, Springer, UK, 2009.

Staines, K. E. H., Carrivick, J. L., Tweed, F. S., Evans, A. J., Russell, A. J., Jóhannesson, T., and Roberts, M.: A multidimensional analysis of pro-glacial landscape change at Sól- heimajökull, southern Iceland, Earth Surf. Proc. Land., 40, 809822, doi:10.1002/esp.3662, 2014.

Stapleton, L. M., Crout, N. M. J., Sawstrom, C., Marshall, W. A., Poulton, P. R., Tye, A. M., and Laybourn-Parry, J.: Microbial carbon dynamics in nitrogen amended Arctic tundra soil: Measurement and model testing, Soil Biol. Biochem., 37, 2088-2098, doi:10.1016/j.soilbio.2005.03.016, 2005.

Stibal, M., Tranter, M., Benning, L. G., and Rehak, J.: Microbial primary production on an Arctic glacier is insignificant in comparison with allochthonous organic carbon input, Environ. Microbiol., 10, 2172-2178, doi:10.1111/j.1462-2920.2008.01620.x, 2008.

Strauss, S. L., Garcia-Pichel, F., and Day, T. A.: Soil microbial carbon and nitrogen transformations at a glacial foreland on Anvers Island, Antarctic Peninsula, Polar Biol., 35, 1459-1471, doi:10.1007/s00300-012-1184-5, 2012.

Telling, J., Anesio, A. M., Tranter, M., Irvine-Fynn, T., Hodson, A., Butler, C., and Wadham, J.: Nitrogen fixation on Arctic glaciers, Svalbard, J. Geophys. Res.-Biogeo., 116, G03039, doi:10.1029/2010jg001632, 2011.

Telling, J., Stibal, M., Anesio, A. M., Tranter, M., Nias, I., Cook, J., Bellas, C., Lis, G., Wadham, J. L., Sole, A., Nienow, P., and Hodson, A.: Microbial nitrogen cycling on the Greenland Ice Sheet, Biogeosciences, 9, 2431-2442, doi:10.5194/bg-9-24312012, 2012.

Toal, M. E., Yeomans, C., Killham, K., and Meharg, A. A.: A review of rhizosphere carbon flow modelling, Plant Soil, 222, 263-281, doi:10.1023/A:1004736021965, 2000.

Tscherko, D., Rustemeier, J., Richter, A., Wanek, W., and Kandeler, E.: Functional diversity of the soil microflora in primary succession across two glacier forelands in the Central Alps, Eur. J. Soil Sci., 54, 685-696, doi:10.1046/j.1365-2389.2003.00570.x, 2003.

Vandewerf, H. and Verstraete, W.: Estimation of Active Soil Microbial Biomass by Mathematical-Analysis of Respiration Curves Development and Verification of the Model, Soil Biol. Biochem., 19, 253-260, doi:10.1016/0038-0717(87)90006-X, 1987.

Wang, Y. P., Chen, B. C., Wieder, W. R., Leite, M., Medlyn, B. E., Rasmussen, M., Smith, M. J., Agusto, F. B., Hoffman, F., and Luo, Y. Q.: Oscillatory behavior of two nonlinear microbial models of soil carbon decomposition, Biogeosciences, 11, 18171831, doi:10.5194/bg-11-1817-2014, 2014.

Yde, J. C., Finster, K. W., Raiswell, R., Steffensen, J. P., Heinemeier, J., Olsen, J., Gunnlaugsson, H. P., and Nielsen, O. B. Basal ice microbiology at the margin of the Greenland ice sheet, Ann. Glaciol., 51, 71-79, 2010.

Yoshitake, S., Uchida, M., Koizumi, H., Kanda, H., and Nakatsubo, T.: Production of biological soil crusts in the early stage of primary succession on a High Arctic glacier foreland, New Phytol., 186, 451-460, doi:10.1111/j.1469-8137.2010.03180.x, 2010.

Zdanowski, M. K., Zmuda-Baranowska, M. J., Borsuk, P., Swiatecki, A., Gorniak, D., Wolicka, D., Jankowska, K. M., and Grzesiak, J.: Culturable bacteria community development in postglacial soils of Ecology Glacier, King George Island, Antarctica, Polar Biol., 36, 511-527, doi:10.1007/s00300-012-1278-0, 2013.

Zelenev, V. V., van Bruggen, A. H. C., and Semenov, A. M.: "BACWAVE", a spatial-temporal model for traveling waves of bacterial populations in response to a moving carbon source in soil, Microb. Ecol., 40, 260-272, 2000. 
Zhang, X. Y., Wang, W., Chen, W. L., Zhang, N. L., and Zeng, H.: Comparison of Seasonal Soil Microbial Process in SnowCovered Temperate Ecosystems of Northern China, Plos One, 9, e92985, doi:10.1371/journal.pone.0092985, 2014.

Ziolek, M. and Melke, J.: The impact of seabirds on the content of various forms of phosphorus in organic soils of the Bellsund coast, western Spitsbergen, Polar Res., 33, 19986, doi:10.3402/polar.v33.19986, 2014.

Zumsteg, A., Bernasconi, S. M., Zeyer, J., and Frey, B.: Microbial community and activity shifts after soil transplantation in a glacier forefield, Appl. Geochem., 26, S326-S329, doi:10.1016/j.apgeochem.2011.03.078, 2011.
Zumsteg, A., Luster, J., Goransson, H., Smittenberg, R. H., Brunner, I., Bernasconi, S. M., Zeyer, J., and Frey, B.: Bacterial, Archaeal and Fungal Succession in the Forefield of a Receding Glacier, Microb. Ecol., 63, 552-564, doi:10.1007/s00248-0119991-8, 2012.

Zumsteg, A., Schmutz, S., and Frey, B.: Identification of biomass utilizing bacteria in a carbon-depleted glacier forefield soil by the use of 13C DNA stable isotope probing, Env. Microbiol. Rep., 5, 424-437, doi:10.1111/1758-2229.12027, 2013. 